\title{
STUDY OF PHASE TRANSFORMATIONS IN COMPLEX PHASE STEEL USING A MESOSCALE CELLULAR AUTOMATON MODEL PART I: MODELING FUNDAMENTALS
}

\author{
BADANIA PRZEMIAN FAZOWYCH W STALI WIELOFAZOWEJ ZA POMOCĄ \\ MEZOSKALOWEGO MODELU AUTOMATU KOMÓRKOWEGO \\ CZĘŚĆ I: PODSTAWY MODELOWANIA
}

\begin{abstract}
A two-dimensional mesoscale model based on the concept of hybrid cellular automata is developed to study phase transformations in a complex phase steel during continuous cooling. The model is capable of simulating microstructure evolution with carbon diffusion in the volume and along grain boundaries, $\gamma / \alpha$ interfaces migration into austenite, as well as formation of bainite and martensite islands during intensive cooling in lower temperatures. In contrast to the classic statistical approaches which are based on the assumption of modeling one point in the material with homogeneous microstructure, the proposed phase transformations' model in the mesoscale accounts for material heterogeneity. The simulation results in the form of a digital material representation with microstructures and maps showing the carbon concentration field as well as microhardness distribution are presented. One of the main advantages of the model is that has only seven adjustment coefficients that are used in the fitting process.
\end{abstract}

Keywords: phase transformations, complex phase steel, cellular automata, mesoscale model
Dwuwymiarowy mezoskalowy model oparty na koncepcji hybrydowych automatów komórkowych zostat opracowany $w$ celu badania przemian fazowych $w$ stali wielofazowej podczas ciagtego chłodzenia. Model umożliwia symulację rozwoju mikrostruktury wraz $z$ dyfuzja węla $w$ objętości, jak i wzdtuz granic ziaren oraz migracja powierzchni międzyfazowych $\gamma / \alpha$ do austenitu, a także powstawaniem wysp bainitu i martenzytu podczas intensywnego chtodzenia $w$ nizssych temperaturach. W odróżnieniu od klasycznych podejść statystycznych, które bazują na zatożeniu modelowania jednego punktu $w$ materiale o jednorodnej mikrostrukturze, zaproponowany model przemian fazowych $w$ mezoskali umożliwia uwzględnienie warunków niejednorodności materiału. Zaprezentowano wyniki symulacji $w$ postaci cyfrowej reprezentacji materiatu z mikrostrukturami oraz mapami przedstawiajacymi pola stężenia węgla oraz rozktady mikrotwardości. Jedna z gtównych zalet modelu jest to, że regulowany jest tylko za pomoca siedmiu wspótczynników $w$ procesie dopasowania.

Stowa kluczowe: przemiany fazowe, stal wielofazowa, automaty komórkowe, model mezoskalowy

\section{INTRODUCTION}

Nowadays, computational material science plays a significant role in the development and improvement of advanced high strength steels, like for example complex phase (CP) steels being the subject of this paper. Especially, computer modeling of microstructural phenomena in a virtual space, such as phase transformations at the mesoscale level, using mesh numerical methods, gives a significant contribution to this research area, which examples one can find in works [1-4]. It is related to the increased computing power of commonly available computers and the development of numerical discrete methods. One can roughly classify mesoscale models according to different numerical approaches, viz.: finite element (FE) [5, 6], front tracking (FT) in other words vertex [7-9], level set (LS) [10, 11], Monte Carlo (MC) [12-14], phase field (PF)
[4, 15-22], phase field crystal (PFC) [23-25], and cellular automata (CA) [1-3, 26-43] methods. Mentioned methods differ considerably in philosophy, methodology and numerical implementation, but all of them are commonly applied in simulations of microstructure evolution occurring during phase transformations in solid state. In order to better understanding, the modeling concept of metallurgical phenomena at mesoscale, a definition of that intermediate level of microstructure properties $[44,45]$ between the microscale and the nanoscale $\left(10^{-4}-10^{-7} \mathrm{~m}\right)$ is clearly demonstrated in Fig. 1.

Nevertheless, to justify the efficiency of the computational and numerical solutions, there is necessary to involve sophisticated physically-based models that describe evolutions of considered metallurgical phenomena in terms of alloying elements and manufacturing process variables. These models require a lot of work during de- 


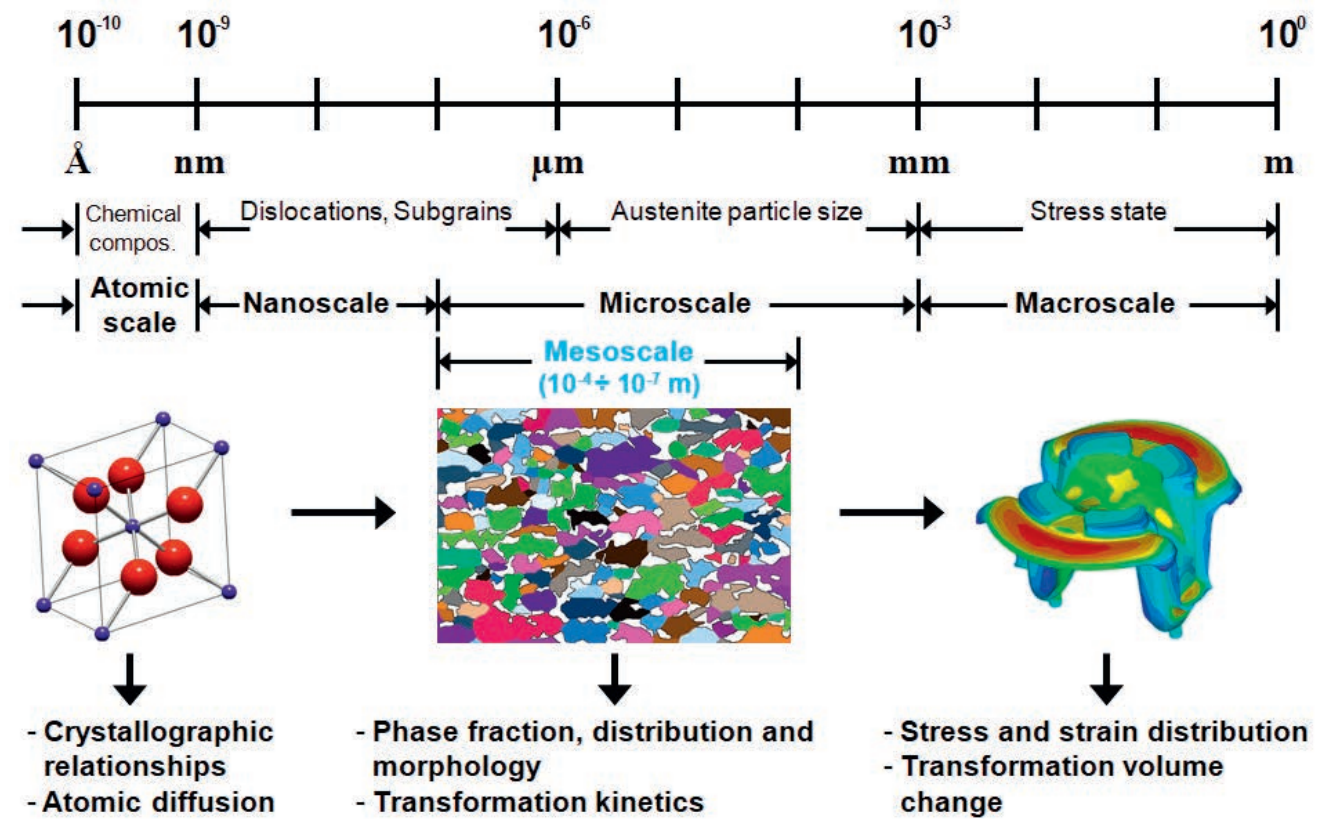

Fig. 1. Scheme presenting length scales of modelling with selected phenomena that can be observed during steel's manufacturing, and definition of the mesoscale term

Rys. 1. Schemat przedstawiający skale modelowania z wybranymi zjawiskami, które można zaobserwować podczas wytwarzania stali, oraz definicja terminu mezoskali

velopment, implementation and are computer time and memory consuming. So one can ask: why computational simulation of microstructure evolution is needed? An answer might seem obscure. Let us consider as an example of the material's design of complex phase steels, which are characterized by high strength and excellent formability [46]. These steels are produced through controlled cooling processes (CCP). Mostly the manufacturing process of steel has a dominant influence on the type of microstructure. In turn, the mechanical properties of CP steels are associated with a specially designed microstructure. Thereupon, the control of supervision of microstructure evolution through optimization of steel chemistry and manufacturing process is pivotal for the best use of CCP and the enhancement of mechanical properties of CP steels. To obtain dedicated microstructure in the course of the material manufacturing processes, an advantage is frequently taken of different microstructural transformation processes that enable producing the desired microstructures in a reproducible way, such as deformation, recrystallization, phase transformation, diffusion, and grain growth. The synergistic effects of the several mentioned phenomena are difficult or even impossible to comprehend, analyze and predict simultaneously. Consequently, on one hand, to produce a particular microstructure, one must understand the kinetic path along which it evolves, and be able to stop its evolution at the appropriate stage of the microstructural transformation process [47]. On the other hand, carrying out hundreds or thousands of physical simulations and laboratory experiments does not guarantee the achievement of the aimed microstructure in the conditions of the material manufacturing processes under complex thermal cycles. Therefore, the development of new CP steel sheets is a substantial problem that requires bear of increased costs and periods of time. Hence, the adoption of the computational tool in three- or four-dimensions (in space and time) to perform microstructure evolution simulations under conditions of the material manufacturing processes is reasonable. Thanks to that, one can dissect the virtual microstructure in space and its evolution in time, and conduct different parameter studies to decide how to improve the manufacturing process [47]. Accordingly, scientific engineers are able to design a particular alloy's chemistry and manufacturing process through set up in a computer of a virtual steel manufacturing process and perform its subsequent simulations.

It is worth pointing out that a comprehensive mesoscale discrete model for all phase transformations of austenite, taking place during cooling (i.e. ferritic, pearlitic, bainitic and martensitic), to the best of our knowledge and recent literature review, has not been yet developed. Usually, solutions for single transformations or a maximum of three are presented. Due to the importance of austenite to ferrite phase transformation during the production of steel, it is one of the most frequently modeled microstructural phenomena, which reflects the number of publications regarding the modeling of this transformation applying the cellular automata method [1, 26-34], as well as using other methods [6, 13, 18-20]. Much less often attempts were made to model only the reverse transformation using CA method, i.e. ferrite into austenite [35-37]. Besides, there exists a large group of works, in which concurrent models, based on the CA method, for both phase transformations were demonstrated [2, 3, 38-40]. The implementation of CA models for other phase transformations does not have such a large representation. Svyetlichnyy and Mikhalyov in work [41] presented a 3D CA model for ferritic and pearlitic transformation. In turn, Pawłowski et al. [42] presented a two-dimensional phase transformation model of austenite into lower bainite. While, Opara et al. [43] proposed a 2D mesoscale modeling of austenite phase transformation into three products, based on the integration of simulation results from three separately defined models for ferritic, bainitic and martensitic transformation, respectively. However, in these models [41-43] too low resolution was used (small discretization density of the modeling area), to 
reflect the morphology of pearlite, bainite or martensite with sufficient accuracy. In the investigated microstructures, these structural components consist of ferrite plates or carbon saturated ferrite laths and dispersion carbide precipitates, which minimum width and length, on the order of $0.01-0.2 \mu \mathrm{m}$ [48], is much smaller than grid size $(\geq 1 \mu \mathrm{m})$ used in developed cellular automata models. For this reason, these models are too much simplification of reality that can be considered as an accurate modeling approach. However, the presented solutions can be treated as a kind of preparation of the basis for the construction of more advanced models of diffusionless and intermediate phase transformations at mesoscale based on the CA method.

The aim of this paper is to present the capabilities of a mesoscale cellular automaton model of phase transformations occurring during complex phase steels cooling with constant rates. In this study, a physically-based mesoscale model with an acronym CAFD2D-SSPT (i.e. Cellular Automata and Finite Difference methods in 2D for Solid State Phase Transformations) is developed to mutually predict the metallurgical mechanisms of carbon diffusion, interface migration during austenite to ferrite phase transformation, and consecutively formation of the other two products of austenite decomposition during intensive cooling in lower temperatures, i.e. bainite and martensite. Specifically, the former phase transformation is modeled taking into account the effect of local carbon redistribution on the migration of the $\gamma / \alpha$ interfaces with the non-equilibrium thermodynamic conditions. Furthermore, in the developed model a higher resolution of the CA grid was used, than in works of other authors [1-3, 26-43], on the level of $10^{-7} \mathrm{~m}$, which allows having regard the surface energy impact, i.e. Gibbs-Thomson effect on the moving $\gamma / \alpha$ interfaces. The simulated results of austenite to ferrite transformation, including the morphology of grains, distribution of phases and carbon concentration field, are the initial conditions for the following simulations of austenite transformations into bainite and martensite. The carbon concentration redistribution in residual austenite grains has especially a dominant influence on the kinetics of bainitic and martensitic transformations, which were modeled through involving relevant thermodynamic criteria. Nevertheless, due to imposed length-scale resolution in the developed model, the latter phase transformations are modeled with necessary simplifications, including the mean field models combined with the CA method.

\section{MODEL CONCEPT}

In this work, a hybrid, two-dimensional computational model, combining cellular automata (CA) and finite difference (FD) methods, is implemented to simulate the microstructure evolution over the solid-state phase transformations in steels during cooling. The cellular automata method is used to model grain growth, and the finite difference method is applied to model the diffusion of carbon in the microstructure. Practically, both models operate on the same data structure representing the microstructure. The concept of CA and FD grids integration is presented in Fig. 2, and it is so called CAFD approach. As one can observe in Fig. 2, an assumption is made that on the CA grid a hypothetical FD mesh is imposed. In fact, the integration points, i.e. the FD mesh nodes, are located in the geometrical centers of gravity of cellular automata. This kind of solution is possible because the used cellular automata grid is regular and modeling of carbon diffusion and grain growth takes place on the same scale - mesoscale. Thanks to that, it is possible to numerically simulate the grain growth of the resulting phase during austenite to ferrite transformation, which is controlled by both carbon diffusion and mobility of the interface.

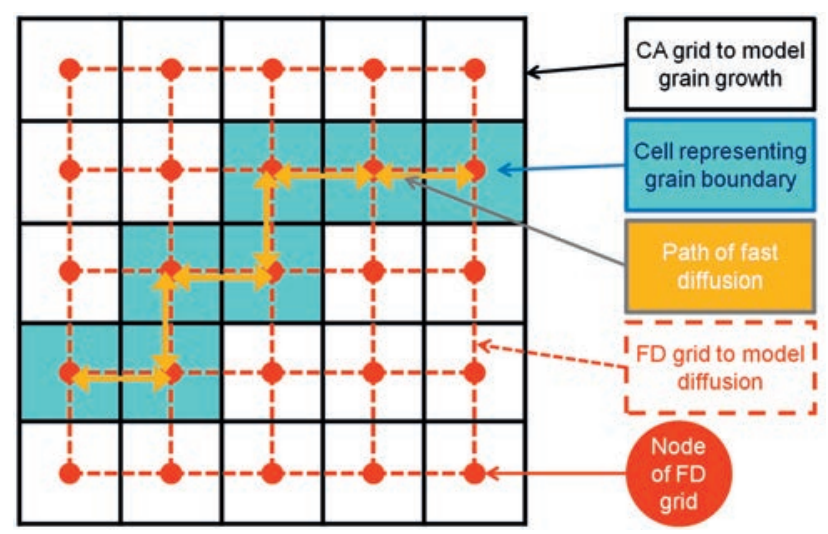

Fig. 2. Grid scheme combining CA and FD methods to model grain growth and carbon diffusion

Rys. 2. Schemat siatki łączącej metody CA oraz FDM do modelowania wzrostu ziarn oraz dyfuzji węgla

In order to model carbon diffusion, the Fick's Second Law is applied and to numerically solve it a forward-time central-space finite difference scheme (FTCS), is used. The FTCS is an explicit scheme [49], which characterizes the simplicity in the mathematical derivation of formulas and in their numerical implementation. This solution allows determining the nodal value of the searched function (in this case i.e. carbon concentration) in the next instant of time based on current values in the surrounding nodes and in it. This approach clearly resembles the fundamentals of the cellular automata method, i.e. the concept of determining the state of the cell based on transition rules. Therefore, the integration of CA and FD-FTCS methods is so intuitive and natural in the implementation. Accordingly, the calculated carbon concentration values are directly assigned to variables from the cellular automata space of states. In this way, the cellular automaton discretizing a section of the modeling space represents the carbon concentration in this micro area.

Similarly, as in other numerical approaches, the solution of the carbon diffusion equation using the finite difference method requires the use of appropriate boundary conditions at the interface between two centers of different physical properties, i.e. in cells representing interfacial boundaries that separate grains belonging to different phases. The first type of boundary condition (i.e. Dirichlet's condition) is determined in these cells based on a mixedmode (MM) approach [50, 51]. With this solution, it is possible to define a nodal value of carbon concentration from the parent phase side $\left(x_{\gamma}^{C, \mathrm{I}}\right)$, and then simulate the formation of carbon concentration profile in front of the moving interface under non-equilibrium thermodynamic conditions (see Fig. 3). Accordingly, the mixed-mode approach enables gradual simulation of diffusive phase transformations in the range of two extreme assumptions: from full control of phase transformation's kinetics by the interface mobility with a limited value (i.e. Interface Controlled mode, IC), to its full control through carbon diffusion in the front of migrating interface (i.e. Diffusion Controlled mode, DC). 
The second type of a boundary condition (i.e. Neumann's condition) is applied at the interface cells based on the Fick's First Law. The idea is presented in Fig. 3 and in the following equation defining a total carbon diffusion flux in the austenite-ferrite interface:

$$
J_{\gamma \rightarrow \alpha}^{C}=J_{\gamma}^{C}-J_{\alpha}^{C}=-D_{\gamma}^{C} \frac{\partial x_{\gamma}^{C}}{\partial n}-\left(-D_{\alpha}^{C} \frac{\partial x_{\alpha}^{C}}{\partial n}\right)
$$

where: $J_{\gamma}^{C}$ and $J_{\alpha}^{C}$ - are carbon diffusion fluxes in the austenite and ferrite, respectively; $D_{\gamma}^{C}$ and $D_{\alpha}^{C}$ - are carbon diffusion coefficients in the austenite and ferrite, respectively; $x_{\gamma}^{C}$ and $x_{\alpha}^{C}$ - are carbon concentrations in the austenite and ferrite, respectively; $n-$ is a coordinate of normal vector to the interphase boundary.

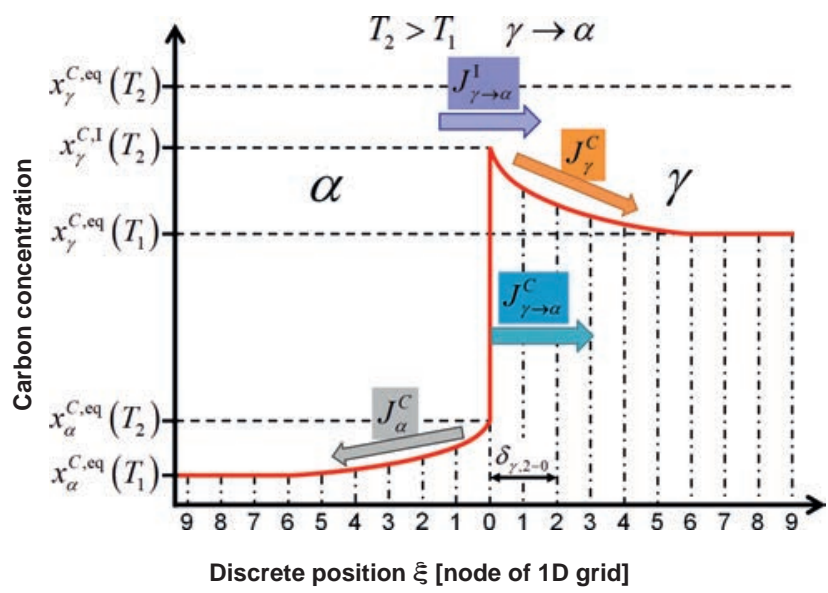

Fig. 3. Scheme showing the carbon concentration profile on a one-dimensional grid together with the established Dirichlet boundary conditions at the interface and carbon diffusion fluxes (i.e. Neumann's condition) formed during the austenite into ferrite phase transformation

Rys. 3. Schemat przedstawiający profil stężenia węgla na jednowymiarowej siatce wraz z ustalonymi warunkami brzegowymi Dirichleta w granicy międzyfazowej oraz strumieniami dyfuzji węgla (tj. warunek Neumanna) powstalymi podczas przemiany fazowej austenitu w ferryt

The net carbon flux $\left(\Delta J_{\gamma \rightarrow \alpha}\right)$ is established at the interface cells' to calculate kinetics of migrating interphase boundaries according to the mixed-mode model [50,51]:

$$
\Delta J_{\gamma \rightarrow \alpha}=J_{\gamma \rightarrow \alpha}^{\mathrm{I}}-J_{\gamma \rightarrow \alpha}^{\mathrm{I}}=\nu^{\mathrm{I}}\left(x_{\gamma}^{C, \mathrm{I}}-x_{\alpha}^{C, \mathrm{eq}}\right)-\left(-D_{\gamma}^{C} \frac{\partial x_{\gamma}^{C}}{\partial n}+D_{\alpha}^{C} \frac{\partial x_{\alpha}^{C}}{\partial n}\right)
$$

where: $J_{\gamma \rightarrow \alpha}^{\mathrm{I}}-$ is a carbon diffusion flux across the austenite-ferrite interface, which is involved by the rearrangement of the crystal structure from austenite to ferrite phase; $v^{\mathrm{I}}$ - is a velocity of the migrating austenite-ferrite interphase boundary; $x_{\alpha}^{\mathrm{C} \text {,eq }}$ - is an equilibrium concentration of carbon in the ferrite phase.

Furthermore, high-diffusivity paths of carbon atoms on the austenite grains boundaries (GB) are included in the model. In Fig. 2 one can observe the scheme with the assumption of privileged diffusion of carbon atoms along austenite grain boundaries on the CAFD grid. The problem is solved using mathematical treatments comparable as in a Fisher's model [52] with a dedicated algorithm to the distinction of carbon diffusion coefficients among other diffusion mechanisms, and solving modified equation with the numerical implementation of the Fick's Second Law as follows:

$$
\begin{aligned}
& x_{\gamma, i, j, t+1}^{C}=\left(1-4 \frac{D_{\gamma}^{C} d t}{\left(\delta_{y, i j}\right)^{2}}\right) x_{\gamma, i, j, t}^{C}+\left(D_{\gamma}^{C, \mathrm{E}} x_{\gamma, i+1, j, t}^{C}\right) \frac{d t}{\left(\delta_{y, i j}\right)^{2}}+ \\
& +\left(D_{\gamma}^{C, \mathrm{w}} x_{\gamma, i-1, j, t}^{C}+D_{\gamma}^{C, \mathrm{~s}} x_{\gamma, i+1, j, t}^{C}+D_{\gamma}^{C, \mathrm{~N}} x_{\gamma, i-1, j, t}^{C}\right) \frac{d t}{\left(\delta_{y, i j}\right)^{2}}+\varepsilon
\end{aligned}
$$

where: $D_{\gamma}^{C, \mathrm{E}}, D_{\gamma}^{C, \mathrm{~W}}, D_{\gamma}^{C, \mathrm{~S}}, D_{\gamma}^{C, \mathrm{~N}}-$ are carbon diffusion coefficients in the E, W, S, N directions, which are properly defined as diffusion coefficients within the austenite grain boundaries or in the volume of austenite depending on whether neighboring cells represent the grain boundary or the interior of the grain, respectively; $i, j$ - are indexes denoting the node number on the spatial grid of the modeled area in two dimensions; $t$ - is an index symbolizing the number of the time step; $d t$ - is time step; $\delta_{\gamma}$ - is the distance between the coordinates (nodes) $i$ or $j$ on a regular square grid; $\varepsilon$ - is a solution error resulting from the accepted residual (accuracy) in the applied differential quotients. The values of Arrhenius's equation coefficients of the volume diffusion and the grain boundary diffusion of carbon in austenite and ferrite microstructure are presented in Table 1. The volume diffusion coefficients are referenced from works [26, 29, 30], whereas diffusion coefficients of carbon along grain boundaries are taken from the work of Suh et al. [53]. Based on this comparison, the following relationship can be formulated, that the preexponential carbon diffusion coefficient at the grain boundary is about 105 times higher than for the volume diffusion, whereas the activation energy of carbon diffusion in GB's, states only about $87 \%$ of its value for the volume diffusion.

As one can observe in Fig. 3 a discretization of the interphase boundaries is based on a sharp interface concept (SI). It means that the nano-area of the interphase boundaries is treated as an infinitesimally thin layer with a practical zero width, in a numerical implementation of the algorithm. In effect, a sharp skip of the physical properties of grains and phases in the modeled area of the interphase boundaries is established. Therefore, the carbon concentration profile, in front of the austenite to ferrite phase transformation, between two separated phases by the interface has a discontinuous character (see Fig. 3).

In mathematical terms, a proposed description of the migrating interfaces in time with the sharp interface concept and a number of carbon diffusion equations coupled by nonlinear boundary conditions at the interphase boundaries is so-called a Stefan problem [54]. A necessary equation to calculate kinetics of the moving $\gamma / \alpha$ interface is formulated by Christian [55] based on an assumption that the boundary velocity is proportional linearly to the driv-

\begin{tabular}{|c|c|c|c|c|c|}
\hline \multicolumn{3}{|c|}{ Pre-exponential carbon diffusion coefficient $\left(\mathrm{m}^{2} \cdot \mathrm{s}^{-1}\right)$} & \multicolumn{3}{|c|}{ Activation energy of carbon diffusion $\left(\mathrm{J} \cdot \mathrm{mol}^{-1}\right)$} \\
\hline Ferrite & Austenite & Austenite GB's & Ferrite & Austenite & Austenite GB's \\
\hline$D_{\alpha}^{C, 0}$ & $D_{\gamma}^{C, 0}$ & $D_{\gamma, G B}^{C, 0}$ & $Q_{a}^{c}$ & $Q_{\gamma}^{c}$ & $Q_{\gamma, G B}^{C}$ \\
\hline $2.00 \cdot 10^{-6}$ & $1.75 \cdot 10^{-5}$ & $1.84 \cdot 10^{-3}$ & 81400 & 143320 & 124995 \\
\hline
\end{tabular}
ing force:

Table 1. Diffusion coefficients of Arrhenius equation, used for the present simulations Tabela 1. Współczynniki dyfuzji w równaniu Arrheniusa, zastosowane w symulacjach 


$$
\nu^{\mathrm{I}}=M_{\gamma \rightarrow \alpha}^{\text {eff }}(\Delta G-2 \sigma \chi)
$$

where: $M_{\gamma \rightarrow \alpha}^{\text {eff }}$ - is an effective mobility of the interface; $\Delta G$ - is a chemical driving force for the austenite to ferrite phase transformation; $\sigma$ - is an interfacial free energy; $x$ - is a curvature of the interface.

Additionally, in the solution of the Stefan problem, as one can see in the right-hand side of equation (4) in the second term of the bracket, the parameters of interfacial free energy and curvature of the interface are included. The influence of these parameters on the boundary conditions determining the kinetics of the moving $\gamma / \alpha$ interface is called as a Gibbs-Thomson effect. Other factors that influence the kinetics of the moving $\gamma / \alpha$ interface are structural effects, such as the degree of coherency of the interface, build-up of stresses generated through volume changes associated with the fcc to bcc lattice change, pinning and solute drag effects. These effects are covered in the model of Stefan problem by the effective mobility, which is assumed to obey an Arrhenius relationship:

$$
M_{\gamma \rightarrow \alpha}^{\text {eff }}=M_{\gamma \rightarrow \alpha}^{0} \exp \left(-\frac{Q_{M}}{R T}\right)
$$

where: $M_{\gamma \rightarrow \alpha}^{0}$ - is a pre-exponential coefficient, which is employed as a fitting parameter and called a mobility factor; $Q_{M}$ - is the activation energy of the interface mobility; $R$ - is the universal gas constant; $T$ - is the absolute temperature.

Finally, a fraction of the growing ferrite phase in a specific cellular automaton can be calculated with the following dependency:

$$
X_{\alpha}=\int_{t_{0}}^{t} \frac{\nu^{\mathrm{I}} d t}{\delta_{C A}} \Re
$$

where: $\delta_{C A}$ - is the automaton cell size both in $x$ and $y$ direction; $\Re$ - is the reduction parameter of an artificial CA grid anisotropy, which is described in detail in Marek's work [56]; $t_{0}$ - is the time when a phase transformation begins.

Before ferrite growth, its nucleation process occurs. Modeling of the ferrite nucleation in the current CAFD2D-SSPT model is based on a Classical Nucleation Theory (CNT) in the form of equation proposed by Cahn [57], which allows determining the dependence of ferrite nucleation on temperature as follows:

$$
I=K_{1} D_{\gamma}^{C}(k T)^{-1 / 2} \exp \left(-\frac{K_{2}}{k T\left(\Delta G_{N}^{\gamma \rightarrow \alpha}\right)^{2}}\right)
$$

where: $I$ - is the nucleation rate of ferrite; $K_{1}$ - is a constant related to the nucleation site density; $K_{2}$ - is a constant related to austenite-ferrite interfacial energy; $k$ - is the Boltzmann constant; $\Delta G_{N}^{\gamma \rightarrow \alpha}$ - is the driving force for the nucleation of ferrite.

Similarly, as in other works $[1,27,31]$, an approach with the integration of the CNT model for the ferrite nucleation with the CA model for ferrite growth is introduced in the current work. In the 2D CA simulations, grain corners (i.e., where four grains meet) are excluded from potential nucleation sites because there is not possible to recognize and define grain corners in a two-dimensional grid with digital microstructure, just like in 2D micrographs of the real material. For more details about geometries of nucleation sites, the reader is referred to the work of Umemoto et al. [58]. Accordingly, an approach of Militzer et al. [19] defining two nucleation modes, namely on triple lines (TL) and on grain surfaces (GS) is utilized, which corresponds approximately to the nucleation on faces and edges of grains. Furthermore, it is assumed that the specific mode of nucleation occurs at a defined nucleation temperature range. The simulation of ferrite nucleation is mainly considered with the TL's mode, which is controlled by additional parameters of nucleation. These adjustable parameters controlling whole nucleation process are well described in work [19] and are as follows: shield distance $\left(\delta_{s d}\right)$, shield time $\left(t_{s t}\right)$, spread of nucleation temperatures for the TL's mode $\left(\delta T_{T L}\right)$ and GS's mode $\left(\delta T_{G S}\right)$, and maximum nucleation temperature $\left(T_{N}\right)$, in which nucleation process can start to occur. The last term is not directly a fitting parameter because it is related to the steady nucleation rate equation (7).

In the developed model of the overall austenite decomposition kinetics, it was assumed that the modeling of the phase transformation of austenite into bainite and martensite is very simplified, compared to the modeling of austenite into ferrite. The length-scale resolution (grid size) in the developed CAFD2D-SSPT model is fixed to the order of $0.08 \mu \mathrm{m}(80 \mathrm{~nm})$, which is too coarse to describe ferrite plates and cementite particles in the bainite structure or martensite laths in martensitic packages separately. Therefore, bainite and martensite formation is modeled with necessary simplifications, including the approach of mean field modeling [59], which is implemented in the CA algorithm. Namely, the structural components, i.e. bainite or martensite, are treated in the modeling space as a homogeneous island or package similarly as was adopted by Bos et al. in work [3], where the pearlite was considered as single phase. The transformations to bainite or martensite occur in different areas of austenite grains and at different times because the driving force to form bainite or martensite from austenite depends on the temperature and local carbon concentration in cellular automata representing grains of residual austenite. Especially the latter factor has a dominant influence on the kinetics of bainitic and martensitic transformations, which were modeled through involving relevant thermodynamic criteria and the carbon concentration limit, i.e. mainly based on $T_{0}$ ' line concept proposed by Bhadeshia and Edmonds [60-62].

The kinetics of bainite transformation under continuous cooling conditions are determined based on the concept of a traditional Scheil-Cahn additivity rule, which provides a mathematical relationship between the transformations that occur under anisothermal conditions and those that occur at constant temperatures [63]. The additivity principle of Scheil-Cahn is an extension in order to predict the incubation time under non-isothermal conditions to a wide range of transformed fractions [55, 63]. In the present instance, the kinetics of bainite growth is defined by the following equation to calculate a transformed bainite fraction in the time interval $d t$ at temperature $T$ :

$$
X_{B}=\int_{t_{0}}^{t} \frac{d t}{\zeta \tau_{B}\left(T, \Delta F_{T_{0}}\right)}
$$

where: $\tau_{B}$ - is the incubation period of bainite transformation at isothermal conditions, which can be calculated based on Russell's expression [64] and Bhadeshia's approach [65]; $\Delta F_{T_{0}}$ - is the free energy change accompanying the formation of bainitic ferrite of the same chemical composition as the austenite; $\zeta$ - is an adjustment parameter, which is used to optimally calibrate the incubation 
period of bainite transformation similarly as was done for theoretical IT diagrams in the work of Joun et al. [66].

The martensite transformation model proposed by Koistinen and Marburger in work [67] is also incorporated into the CAFD2D-SSPT model. This kind of solution was suggested in the work of Bos et al. [38]. The equation of Koistinen and Marburger (K-M) describing the martensite formation is formulated as follows:

$$
X_{M}=1-\exp \left[-0.011\left(M_{s}-T\right]\right.
$$

where: $M_{s}$ - is the start temperature of martensite phase transformation.

The volume fraction of the emerging structural constituent $\left(F_{\varphi}^{C A}\right)$ is calculated in each cellular automaton with interface state, regarding the current volume fraction of remaining austenite at this cell $\left(F_{\gamma}^{C A}\right)$, and the corresponding kinetic equation for the product of phase transformation, which demonstrates the following formula:

$$
F_{\varphi}^{C A}(t+d t)=F_{\gamma}^{C A}(t) X_{\varphi}(t+d t)
$$

where: $\varphi$ - is a symbol of considered structural constituent $(\alpha, B, M)$, i.e. ferrite, bainite, and martensite, respectively. When the volume fraction of a constituent at an individual cell achieves a value of one then this cell is captured and changes its state to identify an emerged structure component. Overall kinetics of the phase transformations occurring in the simulated microstructure is the resultant of the sum of volume fractions from particular cellular automata:

$$
V_{\varphi}=\frac{1}{N_{C A}} \sum_{C A=1}^{N_{C A}} F_{\varphi}^{C A}
$$

where: $V_{\varphi}$ - is the total volume fraction of the considered phase transformation product $(\varphi)$ in the entire space of cellular automata; $N_{C A}$ - is the total number of cellular automata on the grid. Equation (11) is used to calculate the formation progress of all phase transformations' products.

Fig. 4 demonstrates a section of the enlarged digital microstructure representation, in which selected cellular automata representing the interface and the interior of the austenite grains are schematically shown. One can see that in each distinguished cellular automaton the transformation of austenite into ferrite, bainite, or martensite occurred with and without the occurrence of other structural constituents. So, the formation of particular structural components in the CAFD2D-SSPT model can take place at different stages of the simulation according to various scenarios.

When the simulation of phase transformations is completed at room temperature, then mechanical properties can be determined for the simulated microstructure. Because mechanical properties are directly related to the microstructural parameters, in the proposed CAFD2D-SSPT model these properties are determined by incorporating calculations of microhardness for each structural constituent present in the simulated microstructure. And next, mechanical properties such as yield strength (YS) or proof stress, as well as tensile strength (TS) can be calculated applying a simple linear relationship with an average hardness of steel, as follows [68]:

$$
\begin{aligned}
& \mathrm{YS}=A_{Y} H_{\mathrm{V}}+B_{Y} \\
& \mathrm{TS}=A_{T} H_{\mathrm{V}}+B_{Y}
\end{aligned}
$$

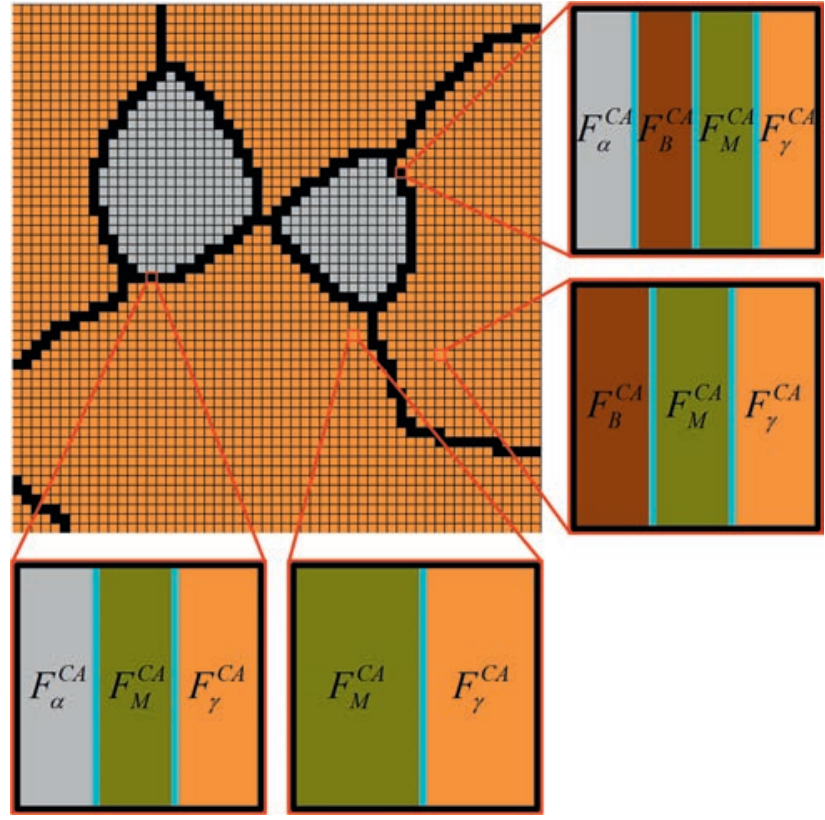

Fig. 4. A section of the enlarged CA grid, which schematically shows cellular automata representing the interface and the interior of the austenite grains, in which the transformation of austenite into ferrite, bainite, and martensite can occur at some stage of the simulation

Rys. 4. Wycinek siatki CA w powiększeniu, na której schematycznie pokazano automaty komórkowe reprezentujące granicę międzyfazową oraz wnętrze ziaren austenitu, w których na pewnym etapie symulacji może nastapić przemiana austenitu $w$ ferryt, bainit oraz martenzyt

where: $A_{Y}, B_{Y}, A_{T}, B_{T}$ - are the fitting coefficients from regression analysis to determine the correlation of the yield strength and tensile strength to the diamond pyramid hardness values (also known as Vickers hardness), based on experimental data, which are presented in Table 2; $H_{\mathrm{V}}$ - is the average Vickers hardness of the microstructure, which can be calculated using the rule of mixtures, as was presented in other works [69, 70]:

$$
H_{\mathrm{V}}=H_{\alpha} V_{\alpha}+H_{B} V_{B}+H_{M} V_{M}
$$

where: $H_{\alpha}, H_{B}$, and $H_{M}$ - are the Vickers hardness of ferrite, bainite, and martensite, respectively; $V_{\alpha}, V_{B}$, and $V_{M}$ - are the volume fraction of ferrite, bainite and martensite, respectively.

In each cellular automaton, the Vickers hardness is calculated locally using structure-property relation models. For the hardness calculations of ferrite and bainite, a model proposed by Yada [71] is used, which reflects a strong dependence of hardness to the mean transformation temperature. This temperature refers to the dislocation density and the solute content in a solid solution. The hardness of martensite is calculated using a dependence proposed by Yurioka et al. in the work [72] concerned with steel welding. The hardness of structural constituents in the simulated microstructure is determined as the arithmetic mean of hardness from the individual CA cells associated with their phase state. Calculated Vickers hardness in particular cellular automata results in the microhardness redistribution, which states a part of the so-called digital material representation.

In order to reproduce the initial microstructure of the investigated CP steel for numerical simulations, a DMR approach proposed by Opara et al. $[33,73]$ is used. The solu- 
Table 2. The fitting coefficients of mechanical properties from regression analysis of experimental data

Tabela 2. Dopasowane współczynniki właściwości mechanicznych $\mathrm{z}$ analizy regresji danych eksperymentalnych

\begin{tabular}{|c|c|c|c|}
\hline \multicolumn{2}{|c|}{ Yield strength } & \multicolumn{2}{c|}{ Tensile strength } \\
\hline $\boldsymbol{A}_{\mathbf{Y}}\left(\mathbf{M P a} \cdot \mathbf{H V}^{\mathbf{1}}\right)$ & $\boldsymbol{B}_{\mathbf{Y}}(\mathbf{M P a})$ & $\boldsymbol{A}_{\boldsymbol{T}}\left(\mathbf{M P a} \cdot \mathbf{H V}^{\mathbf{1}}\right)$ & $\boldsymbol{B}_{T}(\mathbf{M P a})$ \\
\hline 3.644 & -365.16 & 2.572 & 135.91 \\
\hline
\end{tabular}

tion is based on a dedicated algorithm for the conversion of binary images of the investigated microstructure, obtained from SEM metallographic pictures, into the digital material representation. A result of SEM micrograph conversion into the initial microstructure for numerical simulations is presented in Fig. 5. The DMR model of microstructure (from Fig. $5 b$ ) consists of a grid of $512 \times 444$ square cells, equivalent to an area $40.96 \times 35.52 \mu \mathrm{m}^{2}$ of the SEM micrograph (Fig. 5a). It should be pointed out that the random procedure was used to establish orientations of austenite grains presented with different colors on the digital microstructure depicted in Fig. 5b.

A general idea of data flow and construction of a developed CAFD2D-SSPT model is presented on a scheme in Fig. 6. The model is based on several sub-models and numerical algorithms, which enable to simulate the progress of phase transformations in steels during cooling, i.e. austenite decomposition into ferrite, bainite, and martensite, on the mesoscale level. The basic input includes the temperature-time course, steel chemical composition, calculation results from a thermodynamic model with cru-
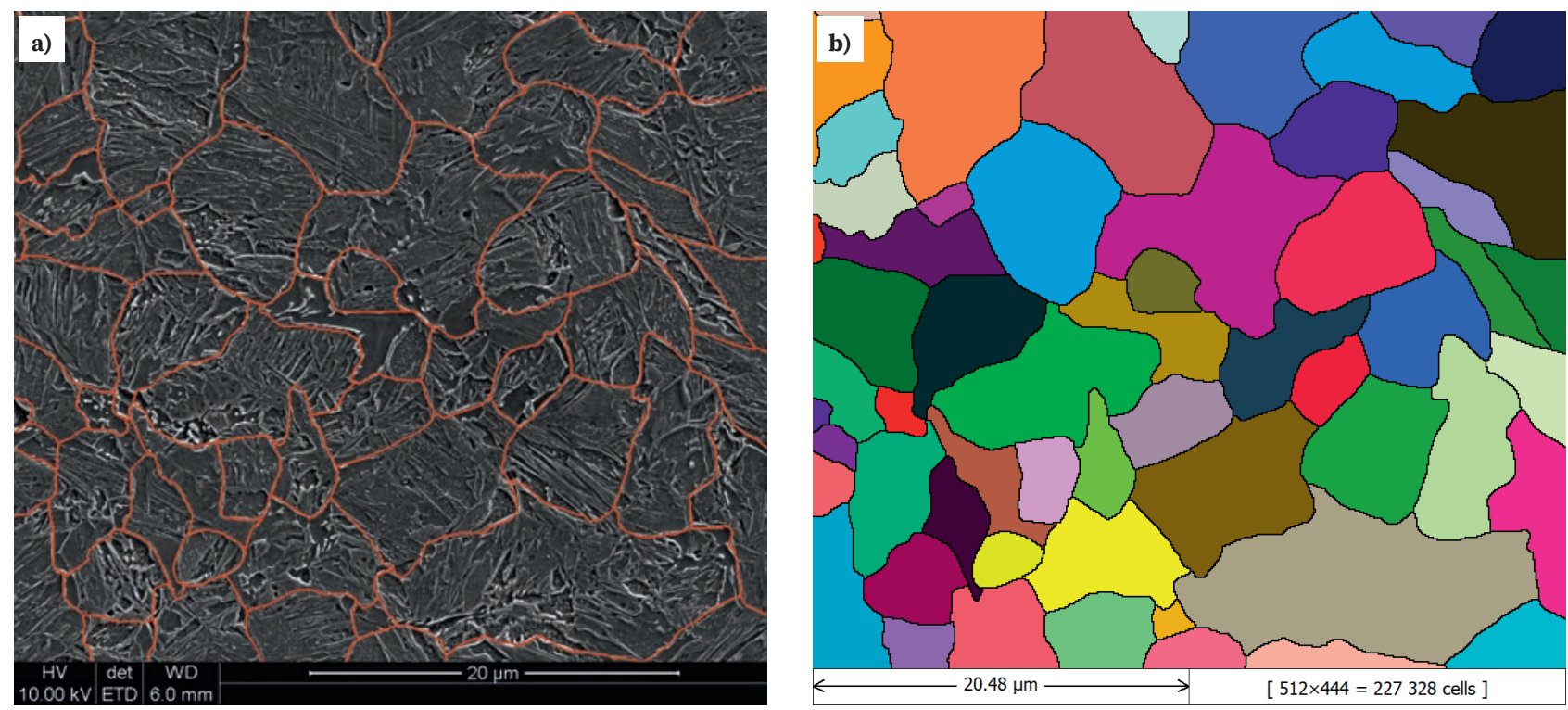

Fig. 5. Image from SEM (a), showing bainitic-martensitic microstructure with revealed and marked grain boundaries of the prior austenite, and a digital representation of the microstructure (b) generated on the CA grid

Rys. 5. Obraz z SEM (a), przedstawiający mikrostrukturę bainityczno-martenzytyczną z ujawnionymi i zaznaczonymi granicami ziarn byłego austenitu, oraz cyfrową reprezentację mikrostruktury (b) wygenerowaną na siatce $\mathrm{CA}$

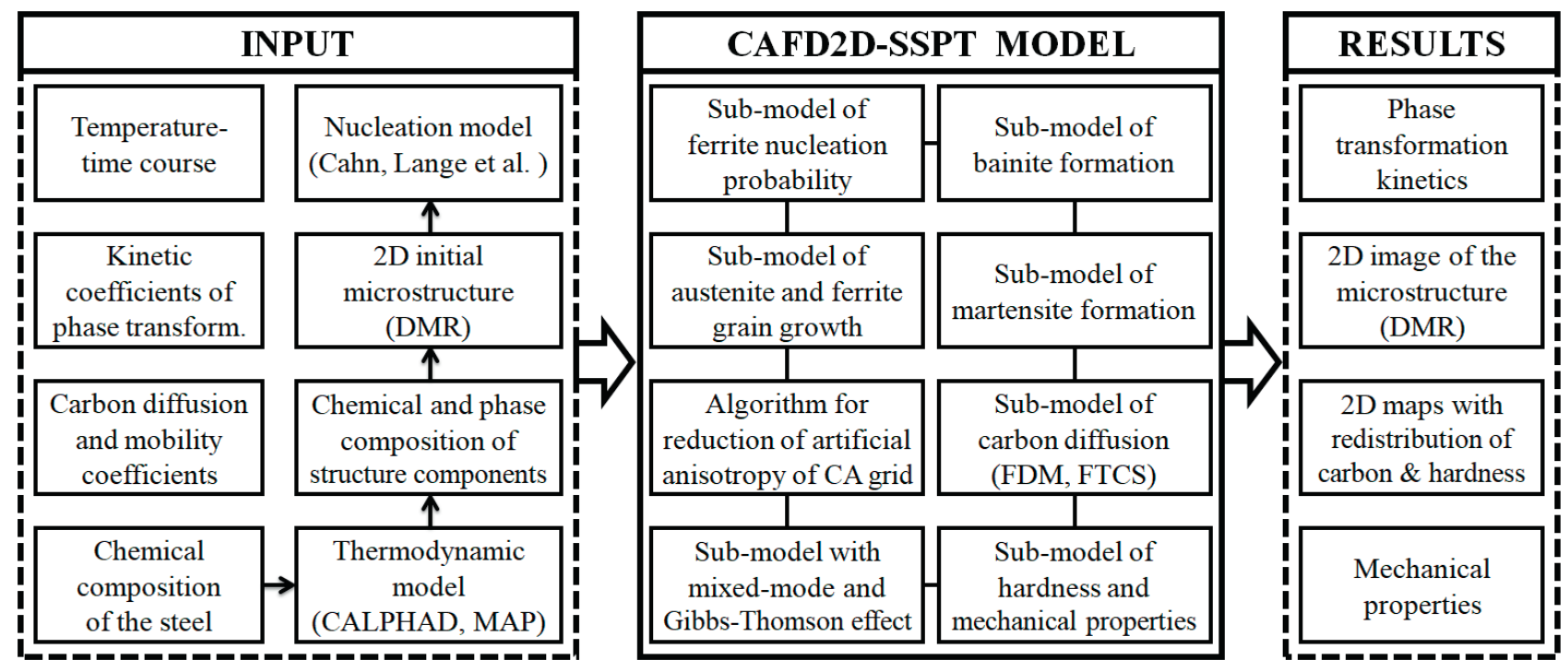

Fig. 6. A diagram showing the approach to comprehensive modeling of solid state phase transformations using the integrated cellular automata and finite difference methods

Rys. 6. Schemat przedstawiający ujęcie kompleksowego modelowania przemian fazowych w stanie stałym za pomocą zintegrowanych metod automatów komórkowych i różnic skończonych 
cial equilibrium parameters as a function of temperature, and the preliminary chemical and phase composition of structure components, digital representation of the initial microstructure, and the results of nucleation model in the form of velocity and nucleation density of ferrite grains. Moreover, the empirical parameters as kinetic coefficients of phase transformations, coefficients of carbon diffusion and interface mobility also are the input data of the CAFD2D-SSPT model. Whereas modeling results include: kinetics of phase transformations and carbon diffusion, two-dimensional images of the digital material representation with simulated microstructures and maps showing carbon concentration field and microhardness distribution in the steel structure, as well as forecasted values of tensile strength, proof stress, and average material hardness. Furthermore, Fig. 6 clearly shows that the developed CAFD2D-SSPT model, consisting of several partial models, is a kind of function that transforms the input data into the final result. And the digital material representation of the microstructure used in the CAFD2D-SSPT model follows the kinetic path to achieve the energy minimum, i.e. the global minimum of the free enthalpy. For more details on the CAFD2D-SSPT model, the mathematical description and model parameters, the reader is referred to the $\mathrm{PhD}$ thesis of the co-author of this work [74].

\section{SIMULATION SETTINGS}

The material used in the study is a CP steel with a chemical composition (wt.\%) of $0.155 \mathrm{C}, 0.389 \mathrm{Si}, 1.531 \mathrm{Mn}, 0.225$ Cr, $0.031 \mathrm{Ni}, 0.004 \mathrm{Mo}, 0.015 \mathrm{Cu}, 0.039 \mathrm{Al}, 0.009 \mathrm{P}, 0.002 \mathrm{~S}$. The investigated steel is signed as CP-IH (Complex Phase - Industrial Heat) due to the material was produced in industrial conditions as a steel strip. The initial conditions for the simulations are established according to the experimental data presented in the next related paper [75]. Based on the chemical composition of the CP-IH steel the thermodynamic data were assigned. The input thermodynamic parameters for the diffusional phase transformation have been determined using a Thermo-Calc software and databases [76]. The partial equilibrium phase diagram $\left(\mathrm{Fe}_{-} \mathrm{Fe}_{3} \mathrm{C}\right)$ for hypereutectoid steel is introduced to the calcu-

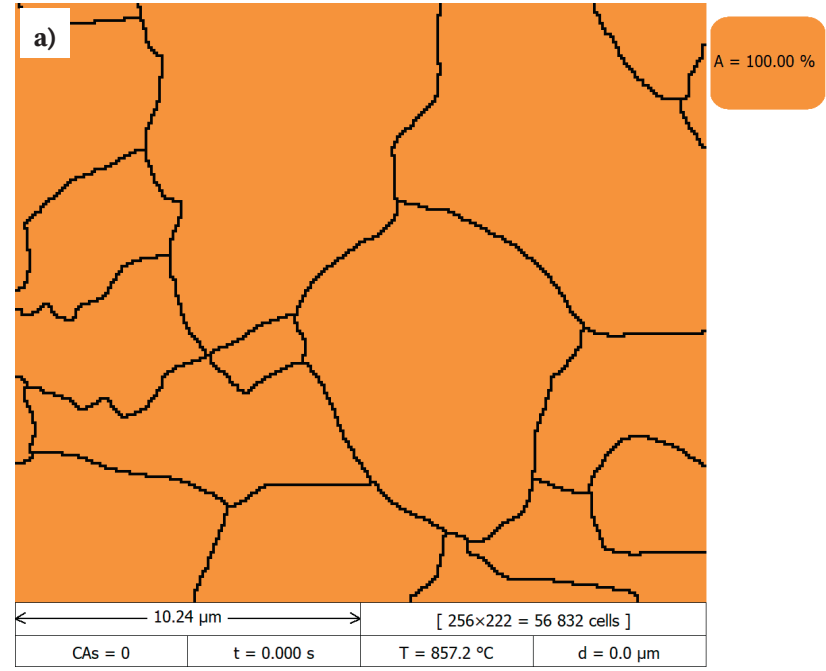

lation algorithm with the CAFD2D-SSPT model in the form of tabular data. The limit lines with carbon concentrations between phases from the $\mathrm{Fe}_{-} \mathrm{Fe}_{3} \mathrm{C}$ diagram are used to establish contact conditions at the interphase boundaries. The driving forces for ferrite nucleation and growth obtained with Thermo-Calc calculations are linearized and implemented into the CAFD2D-SSPT model. Furthermore, it was also necessary to calculate para-equilibrium state parameters for the displacive phase transformations. This issue was realized via a quasi-chemical thermodynamic model, which was proposed by Bhadeshia and Edmonds [60] and expanded in other Bhadeshia's works [61, 62, 65]. The implementation of the quasi-chemical thermodynamic model in the form of an additional module of the $\mathrm{C}++$ computer program with the CAFD2D-SSPT model is based on the Fortran source codes from a Materials Algorithms Project (MAP) [77]. With this solution, thermodynamic calculations are performed online during temperature changes in the system.

The starting microstructure for the simulation, i.e. a prior austenite microstructure of the investigated $\mathrm{CP}-\mathrm{IH}$ steel, is defined based on the DMR model demonstrated in Fig. 5b. In order to reduce computational complexity only a quarter of the DMR grid was used in numerical simulations. The automaton cell size $\left(\delta_{C A}\right)$ equals $0.08 \mu \mathrm{m}$. In effect, the initial calculation domain is defined by a twodimensional $256 \times 222$ square grid of cellular automata (see Fig. 7a), representing a physical domain of $20.48 \times 17.76 \mu \mathrm{m}^{2}$ in a real material. The periodic boundary conditions are established in the CA grid. At the beginning of the simulation, the virtual microstructure is initialized as polycrystalline austenite phase with a homogenous carbon concentration equal to average content in the alloy (i.e. 0.155 wt. \%), as shown in Fig. 7b), and with various orientations of grains (see Fig. 5b).

The temperature field is assumed to be uniform throughout the cellular automata space, because of the mesoscopic scale of the modeling area. In effect, temperature changes are defined globally for the whole CA grid accordingly to current values of the thermal cycle. The thermal treatments implemented in the computer simulations are directly copied from the experimental cooling curves with rates $50^{\circ} \mathrm{C} / \mathrm{s}, 77^{\circ} \mathrm{C} / \mathrm{s}, 97^{\circ} \mathrm{C} / \mathrm{s}$ and $207^{\circ} \mathrm{C} / \mathrm{s}$, which are present-

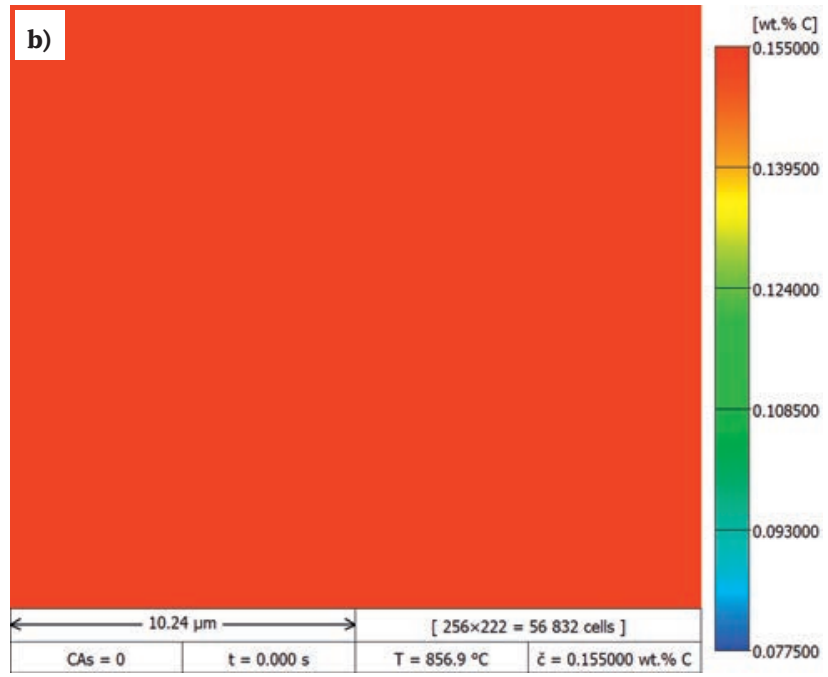

Fig. 7. Digital material representation of the initial microstructure (b), with dimensions of $256 \times 222$ cells, which was used in the simulations of phase transformations during continuous cooling

Rys. 7. Cyfrowa reprezentacja mikrostruktury początkowej, o wymiarach $256 \times 222$ komórek, którą zastosowano w symulacjach przemian fazowych podczas ciagłego chłodzenia 
Table 3. The fitting parameters of sub-models, used in simulations

Tabela 3. Współczynniki dopasowania modeli cząstkowych, zastosowane w symulacjach

\begin{tabular}{|c|c|c|c|c|c|c|c|c|}
\hline \multirow{2}{*}{ Model } & \multirow{2}{*}{ Parameter } & \multirow{2}{*}{ Unit } & \multicolumn{2}{|c|}{ Reference } & \multicolumn{4}{|c|}{ Cooling rates } \\
\hline & & & Value & Source & $50^{\circ} \mathrm{C} / \mathrm{s}$ & $77^{\circ} \mathrm{C} / \mathrm{s}$ & $97^{\circ} \mathrm{C} / \mathrm{s}$ & $207^{\circ} \mathrm{C} / \mathrm{s}$ \\
\hline \multirow{5}{*}{ Ferrite nucleation } & $K_{2}$ & $\mathrm{~J}^{3} \cdot \mathrm{mol}^{-2}$ & $6.33 \cdot 10^{-15}$ & {$[58]$} & $1.1 \cdot 10^{-15}$ & $1.9 \cdot 10^{-15}$ & $3.9 \cdot 10^{-15}$ & $9.8 \cdot 10^{-15}$ \\
\hline & $\delta T_{T L}$ & ${ }^{\circ} \mathrm{C}$ & 16 & {$[19]$} & 60 & 53 & 49 & 40 \\
\hline & $\delta T_{G S}$ & ${ }^{\circ} \mathrm{C}$ & 15 & [19] & 80 & 84 & 100 & 114 \\
\hline & $\delta_{s d}$ & - & - & {$[19]$} & 9 & 9 & 13 & 10 \\
\hline & $t_{s t}$ & $\mathrm{~s}$ & - & [19] & 2.75 & 1.80 & 2.45 & 2.50 \\
\hline Ferrite growth & $M_{\gamma \rightarrow \alpha}^{0}$ & $\mathrm{~mol} \cdot \mathrm{m} \cdot \mathrm{J}^{-1} \cdot \mathrm{s}^{-1}$ & 0.68 & {$[3]$} & 0.0701 & 0.1143 & 0.1097 & 450 \\
\hline Bainite formation & $\zeta$ & - & $0.1-5$ & {$[66]$} & 0.12380 & 0.11185 & 0.08298 & 0.06060 \\
\hline
\end{tabular}

ed in detail in the related paper [75]. The cooling scenarios are simulated to study the effect of cooling rates on microstructural phenomena during austenite decomposition, i.e. ferrite nucleation and growth, carbon diffusion in residual austenite, and formation of bainite and martensite. The key fitting parameters used in the simulations of phase transformations are listed in Table 3. Although, the simulations of the martensitic transformation were performed with the standard values of sub-model coefficients, which are established in equation (9), because it is the last phase transformation during austenite decomposition, and the initial conditions for this transformation are the resultant of modeling preceded phase transformations. Other modeling parameters like the activation energy of the interface mobility $\left(Q_{M}=140000 \mathrm{~J} \cdot \mathrm{mol}^{-1}\right)$, the interfacial free energy $\left(\sigma=0.56 \mathrm{~J} \cdot \mathrm{m}^{-2}\right)$, and the constant related to the nucleation site density of ferrite $\left(K_{1}=2.07 \cdot 10^{11} \mathrm{~J}^{0.5} \cdot \mathrm{m}^{-4}\right)$, are used with typical values, which are well known from the literature $[3,13,58]$, respectively.

\section{SIMULATION RESULTS AND DISCUSSION}

The simulation results in the form of DMR, obtained after investigating the effects of cooling with four constant rates $\left(50^{\circ} \mathrm{C} / \mathrm{s}, 77^{\circ} \mathrm{C} / \mathrm{s}, 97^{\circ} \mathrm{C} / \mathrm{s}\right.$ and $\left.207^{\circ} \mathrm{C} / \mathrm{s}\right)$ on microstructure evolution, during numerical experiments are shown in Fig. 8. Within this range of cooling rates, only phase transformations of austenite into ferrite, bainite, and martensite occur. At a cooling rate of $50^{\circ} \mathrm{C} / \mathrm{s}$, ferrite grains take globular shapes, and in some places similar to polygons, which average equivalent diameter is about $2.6 \mu \mathrm{m}$. Subsequently, with the increase in cooling rate to $97^{\circ} \mathrm{C} / \mathrm{s}$, the average size of ferrite grains decreases and morphology changes gradually, with ferrite grains retaining shapes similar to polygons. However, at more than twice the cooling rate, i.e. $207^{\circ} \mathrm{C} / \mathrm{s}$, the process of ferrite nucleation dominated over the grain growth process, which resulted in a greater number of ferrite grains with a relatively small equivalent diameter of about $1.9 \mu \mathrm{m}$. This is due to the significant undercooling of the system, which resulted in the formation of a high driving force of nucleation. The obtained ferrite grains in the structure have elongated shapes along the austenite grain boundaries, which is the effect of accelerated migration of interphase boundaries along the high-diffusivity paths of carbon in austenite. Modeling of this effect was possible by a direct solution to the Stefan problem, taking into account the mechanism of the high-diffusivity path of carbon atoms along austenite grains boundaries, which was incorporated in the equation (3), and assuming proper values of diffusion coefficients presented in Table 1. Concluding, as the cooling rate increases in the performed simulations the mean equivalent diameter of ferrite grains visible in the DMR images from Fig. 8 decreases, which is consistent with the experimental observations of the microstructures in real materials. Furthermore, the observed ferrite grains are very fine, which is the effect of ferrite recrystallization processes in the thin cold-rolled steel strip during heating and subsequently obtained small prior austenite grain size before cooling.

The bainite and martensite structures on the DMR images from Fig. 8 are presented in the form of uniform islands without distinguishing the morphological features of each structural component. Furthermore, in some results, for example, depicted in Fig. 8a and Fig. 8b, the bainite islands are not visible in the microstructure, but markers with the particular structural components' volume fractions indicate that bainite is present in the material. This case requires an explanation. It arises from the modeling concept of austenite phase transformation into bainite and martensite in the individual cellular automaton, which is schematically shown in Fig. 4. According to the adopted assumptions in the CAFD2D-SSPT model, bainite and martensite can be formed in the same CA cell depending on the value of the energy criterion and the local critical temperature. It may happen that with some supercooling, the martensitic transformation occurs after the bainitic one at a given cellular automaton. Depending on which structural component volume fraction exceeds $50 \%$ in a given cellular automaton, it is considered that it is dominant, and on this basis, the CA state variable, the so-called a phase identifier is assigned to this structure component. As a result, in the digital material representation images of the microstructure, only the structural components that predominate in individual cellular automata are visible. As one can observe in Fig. $8 \mathrm{c}$ and Fig. $8 \mathrm{~d}$ with simulated microstructures for higher cooling rates, the bainite has formed in the interior of residual austenite grains at the later cooling stage (below $600^{\circ} \mathrm{C}$ ). These regions far away from the $\gamma / \alpha$ interfaces retain their initial austenitic carbon concentration (see Fig. 9c and Fig. 9d), where the stability criterion of austenite was the lowest, and which favorites the bainite transformation. While martensite was formed at lower temperatures near to the front of $\gamma / \alpha$ interfaces, where the gradient of carbon concentration was developed in narrow and sharp layers. However, in some regions with the highest carbon concentration, where the austenite was most stable, the transformation into martensite did not proceed, and in effect, trace amounts of the residual austenite can be observed in the simulated microstructures. 

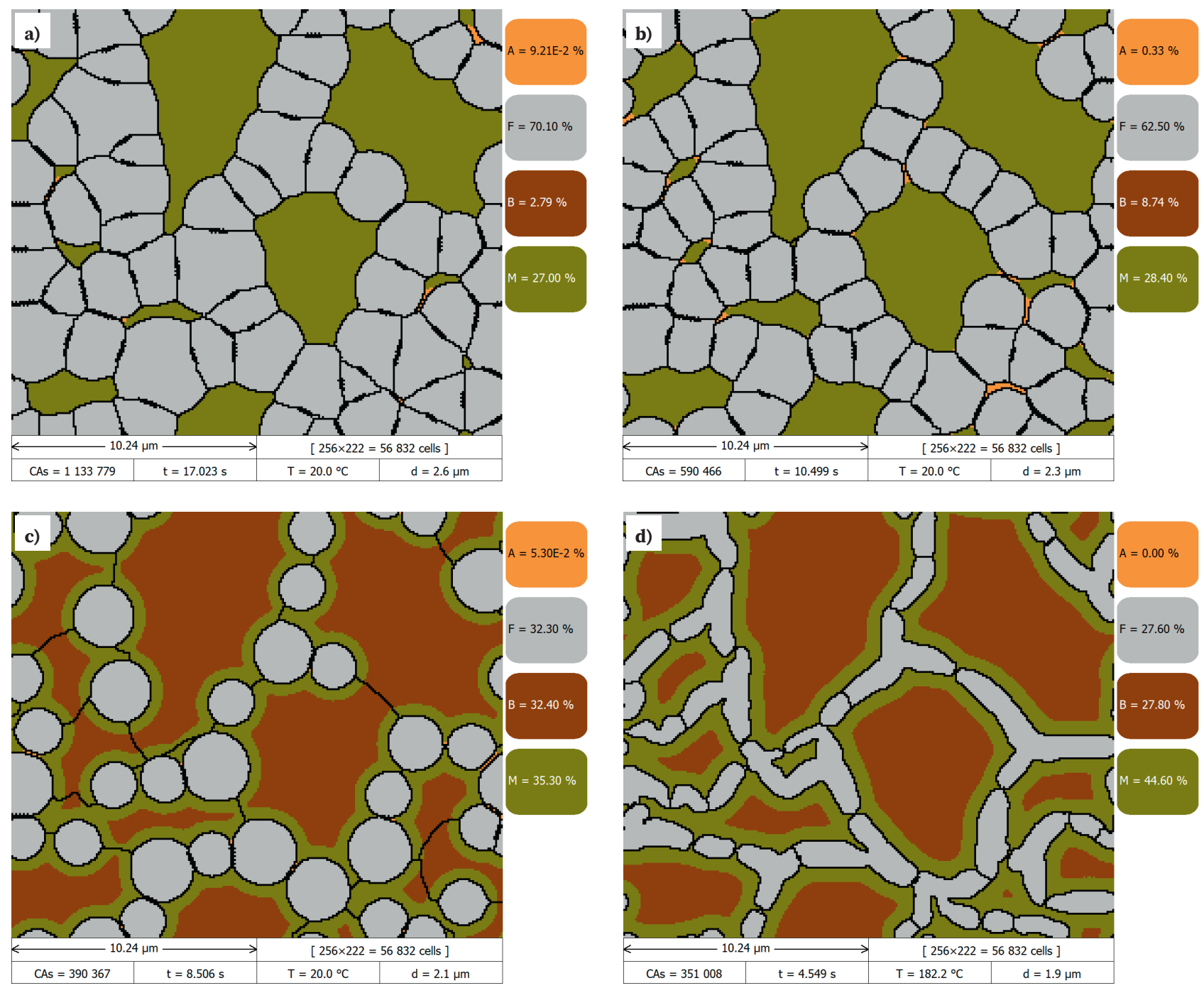

Fig. 8. Simulation results for CP-IH steel, in the form of digital images of the microstructure at the end of cooling at room temperature, after numerical experiments of continuous cooling at rates: (a) $50^{\circ} \mathrm{C} / \mathrm{s}$, (b) $77^{\circ} \mathrm{C} / \mathrm{s}$, (c) $97^{\circ} \mathrm{C} / \mathrm{s}$, (d) $207^{\circ} \mathrm{C} / \mathrm{s}$

Rys. 8. Wyniki symulacji dla stali CP-IH, w formie cyfrowych obrazów mikrostruktury na końcu chłodzenia przy temperaturze pokojowej, po numerycznych eksperymentach ciąłego chłodzenia z szybkościami: (a) $50^{\circ} \mathrm{C} / \mathrm{s}$, (b) $77^{\circ} \mathrm{C} / \mathrm{s}$, (c) $97^{\circ} \mathrm{C} / \mathrm{s}$, (d) $207^{\circ} \mathrm{C} / \mathrm{s}$

The associated maps with the carbon concentration field to the simulated microstructures from Fig. 8, are presented in Fig. 9. One can see that the carbon concentration is distributed heterogeneously in the microstructures. Furthermore, in some regions, where the prior austenite grains were relatively small and the ferrite formation took place, in front of the $\gamma / \alpha$ interfaces the soft impingement effect (i.e. the overlapping of the carbon concentration fields) is observed among the neighboring ferrite grains. Consequently, in these regions, the austenite to ferrite transformation were gradually inhibited, and at later stages of cooling the austenite was more stable during the displacive transformations. Therefore, the ability to view the simulations' results of the grain growth of arising phases and carbon segregation in the microstructure is very helpful when analyzing and interpreting the mechanisms of the formation of individual phases. It is worth pointing out that the presented effects of carbon redistribution in the simulations were obtained directly through the use of the first and second Fick's laws and numerical implementation of their equations in the CAFD2D-SSPT model. Moreover, there was no need to perform any special assumptions or numerical and mathematical treatments, for example, to include soft impingement effect, as was realized in other works [2, 3, 38], where the direct solution of the diffusion equation according to the second Fick's law was omitted.

Based on the calculations of the kinetics of the diffusional phase transformations, the average temperature of these transformations and the segregation of carbon in the microstructure, it was possible to model microhardness for the investigated steel. In effect, the results in the form of maps with the microhardness distribution, which are presented in Fig. 10, were obtained. The maps with microhardness distribution in Fig. 10 directly correspond to the microstructures of Fig. 8 and the carbon concentration fields, which are shown in Fig. 9. It can be seen that the ferrite grains have the lowest hardness below $80 \mathrm{HV}$, while the martensite islands have the highest average value reaching $560 \mathrm{HV}$. In turn, the average hardness of the bainite islands is between these values. The observed relationships are known from the literature on the subject of hardness testing of microstructures consisting solely of individual structural components.

It should be emphasized that the microhardness distribution is also affected by the redistribution of carbon in the microstructure, which inter alia determines the vol- 

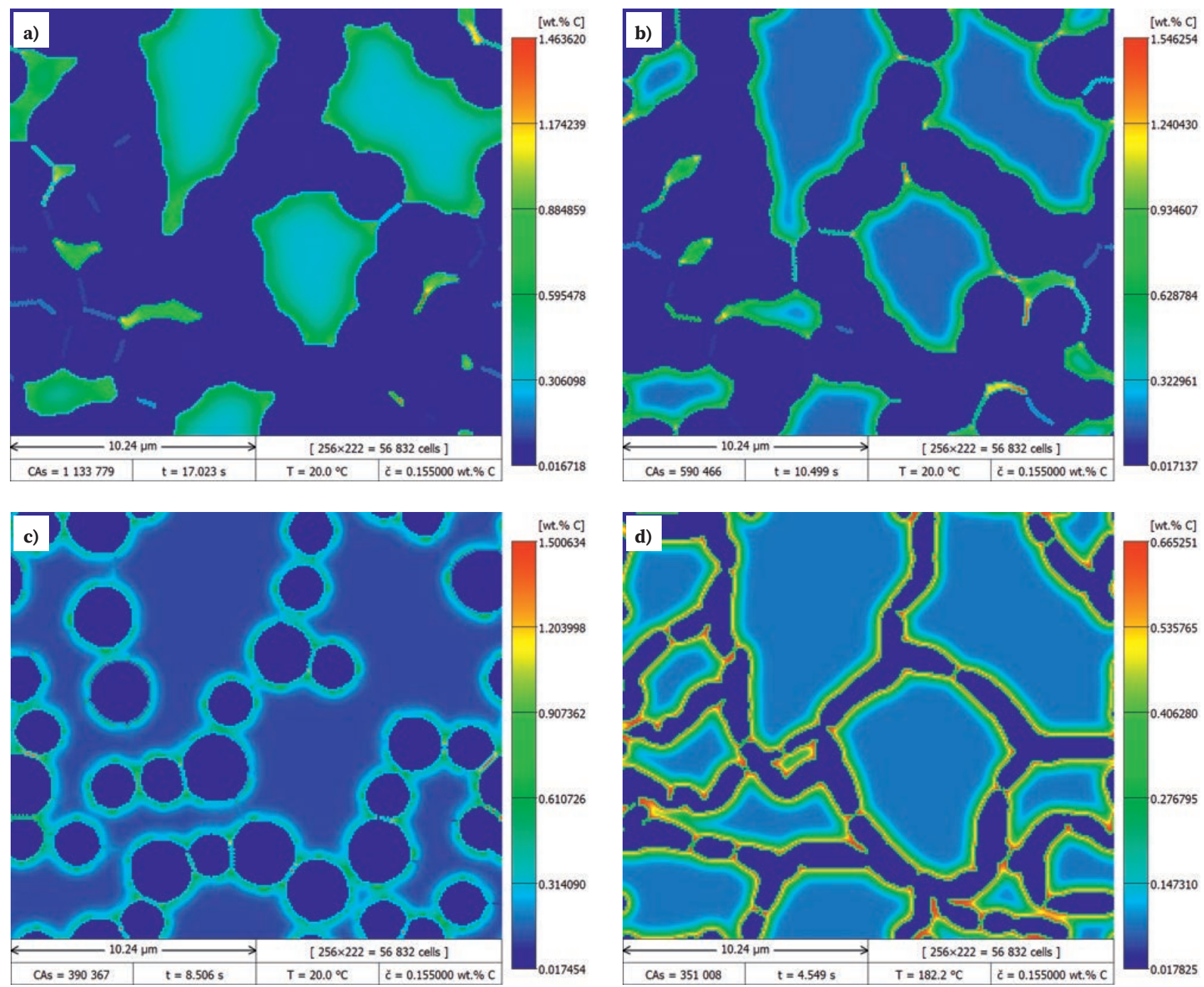

Fig. 9. Simulation results for CP-IH steel, in the form of maps with carbon concentration field in the microstructure at the end of cooling at room temperature, after numerical experiments of continuous cooling at rates: (a) $50^{\circ} \mathrm{C} / \mathrm{s},(\mathrm{b}) 77^{\circ} \mathrm{C} / \mathrm{s},(\mathrm{c}) 97^{\circ} \mathrm{C} / \mathrm{s},(\mathrm{d}) 207^{\circ} \mathrm{C} / \mathrm{s}$

Rys. 9. Wyniki symulacji dla stali CP-IH, w postaci map z polem stężenia węgla w mikrostrukturze na końcu chłodzenia przy temperaturze pokojowej, po numerycznych eksperymentach ciąłłego chłodzenia z szybkościami: (a) $50^{\circ} \mathrm{C} / \mathrm{s},(\mathrm{b}) 77^{\circ} \mathrm{C} / \mathrm{s},(\mathrm{c}) 97^{\circ} \mathrm{C} / \mathrm{s},(\mathrm{d}) 207^{\circ} \mathrm{C} / \mathrm{s}$

ume fraction of martensite and its hardness. In the DMR images from Fig. 10, thin areas of martensite (on the order of several $\mu \mathrm{m}$ ) with very high microhardness reaching up to $918 \mathrm{HV}$ are present. This effect can be explained by the local very high carbon content in these regions about 1.0 wt. \% C (see Fig. 9). Such an effect of locally very high microhardness can also be observed in the work of Springer et al. [78], in which the results are presented in the form of nano-hardness maps analogously to those depicted in Fig. 10. Furthermore, investigation performed by He and Huang [79] using a nanoindentation technique revealed heterogeneous carbon partitioning in medium manganese steel. Bearing in mind the capabilities of the nanoindentation technique, it would be favorable from a verification point of view of the developed microhardness partial model to supplement the current research with nano-hardness measurements, which would allow comparing empirical outcomes with the simulation results from Fig. 10. For each map with microhardness distribution from Fig. 10, the average hardness of the microstructure was calculated according to the law of mixtures (see equation 14), which results are compared with outcomes of hardness measurements in the next related article [75].
It is worth noting that the presented CAFD2D-SSPT model is very compact because includes only seven adjustment coefficients that were used in the fitting process to obtain the good convergence between the simulation and experimental results (see validation results in the related paper [75]). For example, the classic statistical approach for modeling phase transformations based on Johnson-Mehl-AvramiKolmogorov (JMAK) equation contains more than 20 adjustment coefficients [80]. Five fitting parameters are dedicated to the ferrite nucleation sub-model, and one to ferrite growth and one to bainite formation sub-models. Where four parameters in the nucleation sub-model are related directly to the transition rules determining the formation of the ferrite nucleus on the CA grid based on the adopted geometry and undercooling. The latter fitting parameter in the nucleation sub-model is associated with the kinetic type equation (7) like the last two parameters in sub-models for ferrite growth (equation 5) and bainite formation (equation 8). Therefore, these three key fitting parameters of phase transformation kinetics sub-models are analyzed in detail and compiled as a function of the cooling rate in Fig. 11, which can also be found in Table 3. 

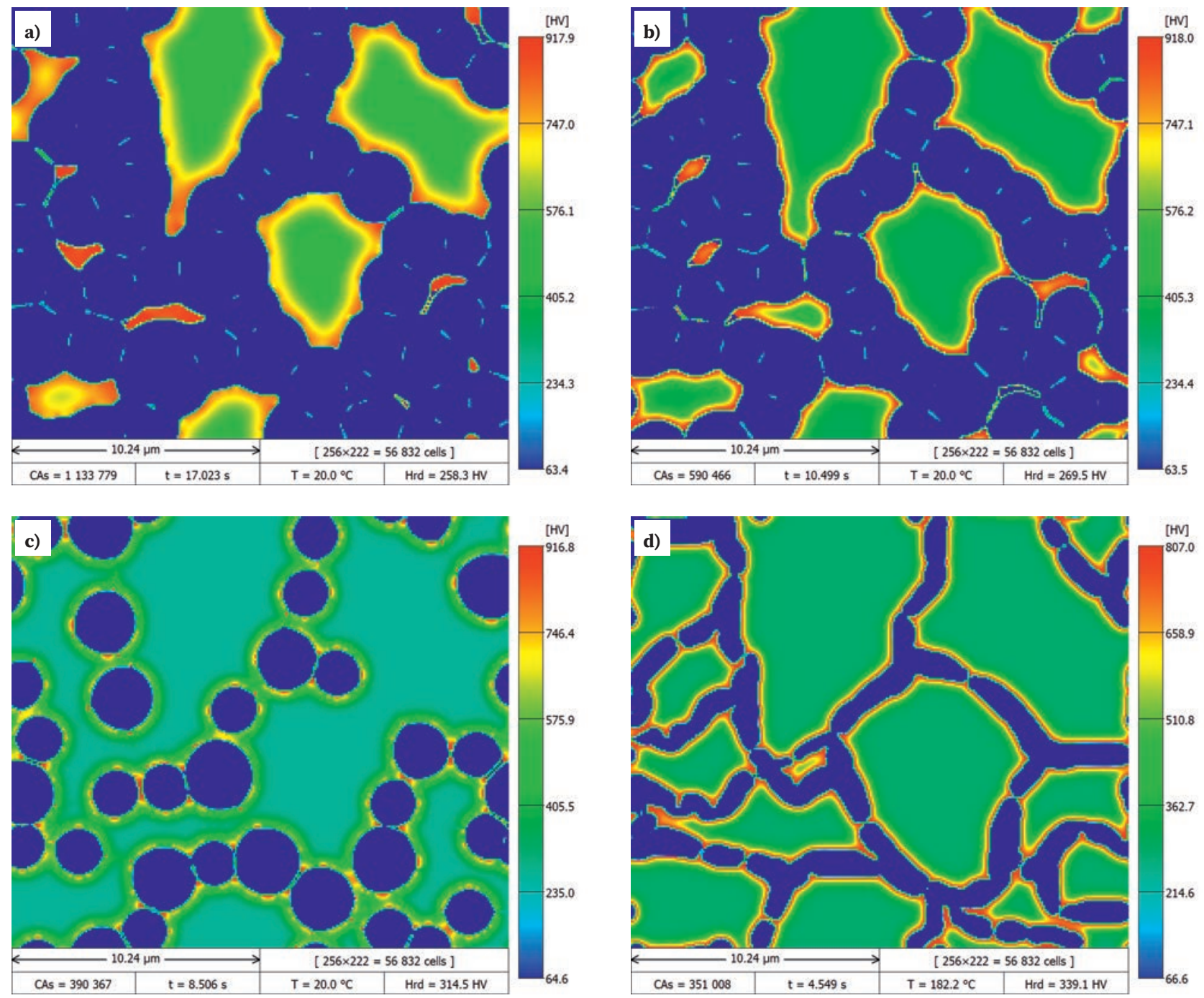

Fig. 10. Results of modeling the hardness distribution in CP-IH steel microstructures, after numerical experiments of continuous cooling at rates: (a) $50^{\circ} \mathrm{C} / \mathrm{s}$, (b) $77^{\circ} \mathrm{C} / \mathrm{s}$, (c) $97^{\circ} \mathrm{C} / \mathrm{s}$, (d) $207^{\circ} \mathrm{C} / \mathrm{s}$

Rys. 10. Wyniki modelowania rozkładu twardości w mikrostrukturach stali CP-IH, po numerycznych eksperymentach cią̧łego chłodzenia z szybkościami: (a) $50^{\circ} \mathrm{C} / \mathrm{s}$, (b) $77^{\circ} \mathrm{C} / \mathrm{s}$, (c) $97^{\circ} \mathrm{C} / \mathrm{s}$, (d) $207^{\circ} \mathrm{C} / \mathrm{s}$

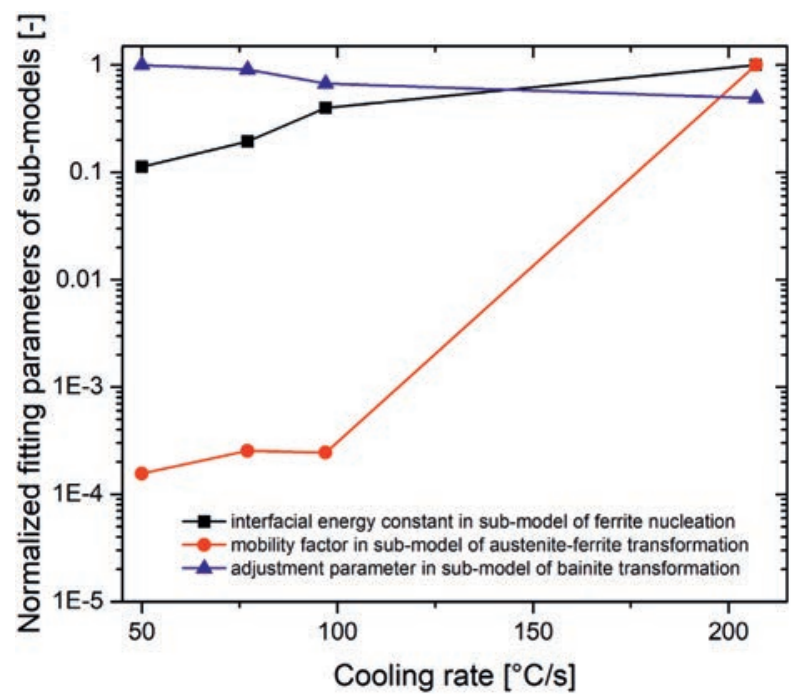

Fig. 11. Normalized fitting parameters of sub-models, which were used in numerical experiments of continuous cooling at rates: $50^{\circ} \mathrm{C} / \mathrm{s}, 77^{\circ} \mathrm{C} / \mathrm{s}, 97^{\circ} \mathrm{C} / \mathrm{s}, 207^{\circ} \mathrm{C} / \mathrm{s}$

Rys. 11. Znormalizowane współczynniki dopasowania podmodeli, które zastosowano $\mathrm{w}$ numerycznych eksperymentach ciągłego chłodzenia z szybkościami: $50^{\circ} \mathrm{C} / \mathrm{s}, 77^{\circ} \mathrm{C} / \mathrm{s}, 97^{\circ} \mathrm{C} / \mathrm{s}$ i $207^{\circ} \mathrm{C} / \mathrm{s}$
The selected coefficients were normalized to present them on one graph with a logarithmic scale for the convenient analysis. As shown in Fig. 11, it should be acknowledged that the fitting parameters of sub-models changes non-linearly with increasing cooling rate. Especially, the mobility factor, i.e. the pre-exponential coefficient of austenite to ferrite phase transformation sub-model, has an irregular course as a function of cooling rate. Therefore, it is not possible to develop a simple linear model to extrapolate fitting parameters beyond the range of investigated cooling rates. One of the solution is taking into account only the lower cooling rates, which would allow to applied some linear relationships, however, the scope of data is not enough to establish a reliable equations in wide range of cooling. Hence there is a need to complement the studies of phase transformations with a greater number of experiments in a specified range of cooling rates.

\section{CONCLUSIONS}

In this work, a two-dimensional mesoscale model based on the concept of hybrid cellular automata is developed to 
study phase transformations in a complex phase steel during continuous cooling. The hybrid character of the model results from the combination of the cellular automata method with the finite difference method, as well as the digital representation of the material. The developed model consists of several sub-models describing metallurgical phenomena and a number of numerical algorithms enabling to distinguish diffusion mechanisms among others including high-diffusivity paths, and taking into account the influence of the segregation of carbon atoms and surface phenomena at the interface on the phase transformations' kinetics.

In the simulations, the initial microstructure was obtained from SEM micrographs using the DMR concept (see Fig. 5), while orientations of austenite grains were established with the random procedure. The presented CAFD2D-SSPT model is capable of simulating microstructure evolution with carbon diffusion in the volume and along grain boundaries, $\gamma / \alpha$ interfaces migration into austenite, as well formation of bainite and martensite islands during intensive cooling in lower temperatures. The austenite to ferrite phase transformation is modeled taking into account the effect of local carbon redistribution on the migration of the $\gamma / \alpha$ interfaces with the non-equilibrium thermodynamic conditions having regard the surface energy impact, i.e. Gibbs-Thomson effect. The austenite to bainite and martensite phase transformations are modeled through involving relevant thermodynamic criteria, and with necessary simplifications due to too low resolution of the CA space by including the mean field modeling approach which is combined with the CA method.

In contrast to the classic statistical approaches, inter alia JMAK model [80], which are based on the assumption of modeling one point in the material with homogeneous microstructure, the proposed phase transformations' model in the mesoscale is developed in terms of material heterogeneity such as crystallography, Gibbs free energy dissipation, chemical composition and morphology of microstructure with many grains belonging to different phases of various sizes, which interact locally with each other, but from a global point of view determine the progress of phase transformations in the alloy at the solid state. The model enables visualization in real-time of the ferrite grains nucleation, their growth, and also bainite and martensite formation during numerical experiments of continuous cooling, which examples are depicted in Fig. 8. Furthermore, one can observe carbon segregation on the front of phase transformations and in the interior of grains, which is presented on the so-called maps of the distribution of elements in the microstructure (see Fig. 9). Consequently, model predicts the microhardness for the investigated steel, which is demonstrated in the form of maps with the microhardness distribution in Fig. 10. The simulated results of austenite to ferrite transformation in the form of heterogeneous microstructure in the DMR, including the morphology of grains, distribution of phases and carbon concentration field, are the initial conditions for the following simulations of austenite transformations into bainite and martensite.

One of the advantages of the presented model is that has only seven adjustment coefficients that are used in the fitting process, which could be convenient for the subsequent sensitivity analysis. However, it should be acknowledged that the fitting parameters of sub-models changes non-linearly with increasing cooling rate. Especially, the mobility factor of austenite to ferrite phase transformation sub-model has an irregular course as a function of cooling rate. Therefore, it is not so obvious to develop a simple linear model to extrapolate fitting parameters beyond the range of investigated cooling rates.

\section{ACKNOWLEDGEMENTS \\ Financial assistance from the Research Fund for Coal and Steel, Grant Agreement number RFSR-CT-2011-00014, is acknowledged.}

\section{REFERENCES}

[1] C.W. Zheng, N. Xiao, L. Hao, D. Li, Y. Li. Numerical simulation of dynamic strain-induced austenite-ferrite transformation in a low carbon steel. Acta Materialia, 2009, 57, p. 2956-2968.

[2] M.G. Mecozzi, C. Bos, J. Sietsma. 3D cellular automata modelling of solid-state transformations relevant in low-alloy steel production. Solid State Phenomena, 2011, 172-174, p. 1140-1145.

[3] C. Bos, M.G. Mecozzi, D.N. Hanlon, M.P. Aarnts, J. Sietsma. Application of a Three-Dimensional Microstructure Evolution Model to Identify Key Process Settings for the Production of Dual-Phase Steels. Metallurgical and Materials Transactions A, 2011, 42, p. $3602-$ 3610.

[4] M.J. Santofimia, L. Zhao, J. Sietsma. Overview of Mechanisms Involved During the Quenching and Partitioning Process in Steels. Metallurgical and Materials Transactions A, 2011, 42, p. 3620-3626.

[5] M. Pernach, K. Bzowski, M. Pietrzyk. Application of numerical solution of the diffusion equation to modelling phase transformation during heating of DP steels in the continuous annealing process. Computer Methods in Materials Science, 2012, 12 (3), p. 183196.

[6] M. Pernach, K. Bzowski, M. Pietrzyk. Numerical modeling of phase transformation in dual phase (DP) steel after hot rolling and laminar cooling. Journal for Multiscale Computational Engineering, 2014, 12 (5), p. 397-410.

[7] K. Nakashima, T. Nagai, K. Kawasaki. Scaling behavior of two-dimensional domain growth: Computer simulation of vertex models. Journal of Statistical Physics, 1989, 57, p. 759-787.
[8] D. Weygand, Y. Bréchet, J. Lépinoux. Reduced Mobility of Triple Nodes and Lines on Grain Growth in Two and Three Dimensions. Interface Science, 1999, 7, p. 285-295.

[9] S. Maddali, S. Ta'asan, R.M. Suter. Topology-faithful nonparametric estimation and tracking of bulk interface networks. Computational Materials Science, 2016, 125, p. 328-340.

[10] E. Javierre, C. Vuik, F. Vermolen, A. Segal, S. van der Zwaag. The Level Set Method for Solid-Solid Phase Transformations. Numerical Mathematics and Advanced Applications, 2006, 18, p. 712-719.

[11] T. Iwamoto, M. Cherkaoui, E.P. Busso. A finite element-based level-set method of an interface motion driven by a diffusion field: Application to a phase transformation problem. Computational Materials Science, 2008, 44, p. 792-801.

[12] Y. Saito, M. Enomoto. Monte Carlo Simulation of Grain Growth. ISIJ International, 1992, 32 (3), p. 267-274.

[13] N. Xiao, M. Tong, Y. Lan, D. Li, Y. Li. Coupled simulation of the influence of austenite deformation on the subsequent isothermal austenite-ferrite transformation. Acta Materialia, 2006, 54, p. $1265-1278$.

[14] D. Zöllner. Treating grain growth in thin films in three dimensions: A simulation study. Computational Materials Science, 2016, 125 , p. $51-60$.

[15] A.A. Wheeler, W.J. Boettinger, G.B. McFadden. Phase-field model for isothermal phase transitions in binary alloys. Physical Review A, 1992, 45, p. 7424-7439.

[16] I. Steinbach, F. Pezzolla, B. Nestler, M. Sedklberg, R. Ptieler, G.J. Schmitz, J.L.L. Rezende. A phase field concept for multiphase systems. Physica D, 1996, 94, p. 135-147. 
[17] J. Tiaden, B. Nestler, H.J. Diepers, I. Steinbach. The multiphase-field model with an integrated concept for modelling solute diffusion. Physica D, 1998, 115, p. 73-86.

[18] C.-J. Huang, D.J. Browne, S. McFadden. A phase-field simulation of austenite to ferrite transformation kinetics in low carbon steels. Acta Materialia, 2006, 54, p. 11-21.

[19] M. Militzer, M.G. Mecozzi, J. Sietsma, S. van der Zwaag. Threedimensional phase field modelling of the austenite-to-ferrite transformation. Acta Materialia, 2006, 54, p. 3961-3972.

[20] A. Yamanaka, T. Takaki, Y. Tomita. Coupled simulation of microstructural formation and deformation behavior of ferrite-pearlite steel by phase-field method and homogenization method. Materials Science and Engineering A, 2008, 480, p. 244-252.

[21] J. Rudnizki, B. Böttger, U. Prahl, W. Bleck. Phase-Field Modeling of Austenite Formation from a Ferrite plus Pearlite Microstructure during Annealing of Cold-Rolled Dual-Phase Steel. Metallurgical and Materials Transactions A, 2011, 42, p. 2516-2525.

[22] M. Düsing, R. Mahnken. A coupled phase-field - Cahn-Hilliard model for lower bainitic transformation. Proceedings in Applied Mathematics and Mechanics, 2015, 15, p. 285-286.

[23] K.R. Elder. M. Katakowski, M. Haataja, M. Grant. Modeling Elasticity in Crystal Growth. Physical Review Letters, 2002, 88, p. 245701245704.

[24] N. Provatas, J.A. Dantzig, B. Athreya, P. Chan, P. Stefanovic, N. Goldenfeld, K.R. Elder. Using the Phase-Field Crystal Method in the Multi-Scale Modeling of Microstructure Evolution. JOM, 2007, 59 (7), p. 83-90.

[25] M. Greenwood, N. Provatas, J. Rottler. Free Energy Functionals for Efficient Phase Field Crystal Modeling of Structural Phase Transformations. Physical Review Letters, 2010, 105, p. 045702-045704.

[26] M. Kumar, R. Sasikumar, P. Kesavan Nair. Competition between nucleation and early growth of ferrite from austenite - studies using cellular automaton simulations. Acta Materialia, 1998, 46, p. 6291-6303.

[27] L. Zhang, C.B. Zhang, Y.M. Wang, S.Q. Wang, H.Q. Ye. A cellular automaton investigation of the transformation from austenite to ferrite during continuous cooling. Acta Materialia, 2003, 51, p. 5519-5527.

[28] S. Kundu, M. Dutta, S. Ganguly, S. Chandra. Prediction of phase transformation and microstructure in steel using cellular automaton technique. Scripta Materialia, 2004, 50, p. 891-895.

[29] Y.J. Lan, D.Z. Li, Y.Y. Li. Modeling austenite decomposition into ferrite at different cooling rate in low-carbon steel with cellular automaton method. Acta Materialia, 2004, 52, p. 1721-1729.

[30] Y.J. Lan, N.M. Xiao, D.Z. Li, Y.Y. Li. Mesoscale simulation of deformed austenite decomposition into ferrite by coupling a cellular automaton method with a crystal plasticity finite element model. Acta Materialia, 2005, 53, p. 991-1003.

[31] D.Z. Li, N.M., Xiao, Y.J. Lan, C.W. Zheng, Y.Y. Li. Growth modes of individual ferrite grains in the austenite to ferrite transformation of low carbon steels. Acta Materialia, 2007, 55, p. 6234-6249.

[32] M. Pietrzyk, Ł. Madej, Ł. Rauch, R. Gołąb. Multiscale modelling of microstructure evolution during laminar cooling of hot rolled DP steels. Archives of Civil and Mechanical Engineering, 2010, 10 (4), p. 57-67.

[33] J. Opara, R. Kuziak, H. Chen, S. van der Zwaag. A two-dimensional CA model to simulate microstructure development and carbon redistribution during the phase transformation of austenite to ferrite using realistic angular starting microstructures. Computer Methods in Materials Science, 2012, 12 (3), p. 207-217.

[34] B.L. Ennis, E. Jimenez-Melero, R. Mostert, B. Santillana, P.D. Lee. The role of aluminium in chemical and phase segregation in a TRIP-assisted dual phase steel. Acta Materialia, 2016, 115, p. 132 142.

[35] B.J. Yang, L. Chuzhoy, M.L. Johnson. Modeling of reaustenitization of hypoeutectoid steels with cellular automaton method. Computational Materials Science, 2007, 41 (2), p. 186-194.

[36] C.W. Zheng, D. Raabe. Interaction between recrystallization and phase transformation during intercritical annealing in a coldrolled dual-phase steel: A cellular automaton model. Acta Materialia, 2013, 61, p. 5504-5517.

[37] C. Jiaa, C.W. Zheng, D., Li. Cellular automaton modeling of austenite formation from ferrite plus pearlite microstructures during intercritical annealing of a C-Mn steel. Journal of Materials Science \& Technology, 2020, 47, p. 1-9.

[38] C. Bos, M.G. Mecozzi, J. Sietsma. A microstructure model for recrystallisation and phase transformation during the dual-phase steel annealing cycle. Computational Materials Science, 2010, 48, p. 692-699.
[39] C.W. Zheng, D. Raabe, D.Z. Li. Prediction of post-dynamic austenite-to-ferrite transformation and reverse transformation in a low-carbon steel by cellular automaton modeling. Acta Materialia, 2012, 60, p. 4768-4779.

[40] D. An, S. Pan, L. Huang, T. Dai, B. Krakauer, M. Zhu. Modeling of Ferrite-Austenite Phase Transformation Using a Cellular Automaton Model. ISIJ International, 2014, 54, p. 422-429.

[41] D.S. Svyetlichnyy, A.I. Mikhalyov. Three-dimensional Frontal Cellular Automata Model of Microstructure Evolution - Phase Transformation Module. ISIJ International, 2014, 54, p. 1386-1395.

[42] G. Jabłoński, B. Pawłowski, M. Pietrzyk. Application of the Cellular Automata method to modelling lower bainite in steels. Computer Methods in Materials Science, 2012, 12, p. 51-62.

[43] J. Opara, G. Jabłoński, D. Rudzki, M. Pietrzyk. Modelowanie metodą automatów komórkowych cyklu przemian fazowych w stalach. Hutnik - Wiadomości Hutnicze, 2012, 79, p. 447-451.

[44] W. Kapturkiewicz, E. Fraś, A.A. Burbelko. Why is the computer modelling needed in casting? Przeglad Odlewnictwa, 2005, 1, p. 1523.

[45] M. Militzer. Computer Simulation of Microstructure Evolution in Low Carbon Sheet Steels. ISIJ International, 2007, 47, p. 1-15.

[46] Future Steel Vehicle. Final Engineering Report, Steel Market Development Institute, Washington, DC, 2011. [Online] Available at: www. autosteel.org [Accessed on: 28 August 2020].

[47] K.G.F. Janssens, D. Rabbe, E. Kozeschnik, M.A. Miodownik, B. Nestler. Computational Materials Engineering. An Introduction to Microstructure Evolution. Oxford: Elsevier Academic Press, 2007.

[48] J.P. Naylor. The influence of the lath morphology on the yield stress and transition temperature of martensitic-bainitic steels. Metallurgical and Materials Transactions A, 1979, 10, p. 861-873.

[49] T.J. Chung. Computational Fluid Dynamics. Cambridge: Cambridge University Press, 2002.

[50] G.P. Krielaart, J. Sietsma, S. van der Zwaag. Ferrite formation in Fe-C alloys during austenite decomposition under non-equilibrium interface conditions. Materials Science and Engineering A, 1997, 237, p. 216-223.

[51] J. Sietsma, S. van der Zwaag. A concise model for mixed-mode phase transformations in the solid state. Acta Materialia, 2004, 52, p. $4143-4152$.

[52] J.C. Fisher. Calculation of Diffusion Penetration Curves for Surface and Grain Boundary Diffusion. Journal of Applied Physics, 1951, 22, p. 74-77.

[53] S.-W.Seo, H.K.D.H. Bhadeshia, D.W. Suh. Pearlite growth rate in Fe-C and Fe-Mn-C Steels. Materials Science and Technology, 2015, 31, p. 487-493.

[54] F. Vermolen, K. Vuik. A numerical method to compute the dissolution of second phases in ternary alloys. Journal of Computational and Applied Mathematics, 1998, 93, p. 123-143.

[55] J.W. Christian. The theory of transformation in metals and alloys, Issue 2. Oxford: Pergamon Press, 1981.

[56] M. Marek. Grid anisotropy reduction for simulation of growth processes with cellular automaton. Physica D, 2013, 253, p. 73-84.

[57] J.W. Cahn. The kinetics of grain boundary nucleated reactions. Acta Metallurgica, 1956, 4, p. 449-459.

[58] M. Umemoto, Z.H. Guo, I. Tamura. Effect of cooling rate on grain size of ferrite in a carbon steel. Materials Science and Technology, 1987, 3, p. 249-255

[59] L. Madej, M. Sitko, M. Pietrzyk. Perceptive comparison of mean and full field dynamic recrystallization models. Archives of Civil and Mechanical Engineering, 2016, 16, p. 569-589.

[60] H.K.D.H. Bhadeshia, D.V. Edmonds. The mechanism of bainite formation in steels. Acta Metalurgica, 1980, 28, p. 1265-1273.

[61] H.K.D.H. Bhadeshia. A rationalisation of shear transformations in steels. Acta Metalurgica, 1981, 29, p. 1117-1130.

[62] H.K.D.H. Bhadeshia. Thermodynamic extrapolation and martensite-start temperature of substitutionally alloyed steels. Metal Science, 1981, 15, p. 178-180.

[63] J.W. Cahn. Transformation kinetics during continuous cooling. Acta Metallurgica, 1956, 4 (6), p. 572-575.

[64] K.C. Russell. Grain boundary nucleation kinetics. Acta Metallurgica, 1969, 17, p. 1123-1131.

[65] H.K.D.H. Bhadeshia. A Thermodynamic analysis of isothermal transformation diagrams. Metal Science, 1982, 16, p. 159-165.

[66] M. Irani, S. Chung, M. Kim, K. Lee, M. Joun. Adjustment of Isothermal Transformation Diagrams Using Finite-Element Optimization of the Jominy Test. Metals, 2020, 10 (7), p. 931.

[67] D.P. Koistinen, R.E. Marburger. A general equation prescribing the extent of the austenite-martensite transformation in pure 
iron-carbon alloys and plain carbon steels. Acta Metallurgica, 1959, 7 (1), p. 59-60.

[68] E.J. Pavlina, C.J. Van Tyne. Correlation of yield strength and tensile strength with hardness for steels. Journal of Materials Engineering and Performance, 2008, 17, p. 888-893.

[69] M.V. Li, D.V. Niebuhr, L.L. Meekisho, D.G. Atteridge. A computational model for the prediction of steel hardenability. Metallurgical and Materials Transactions B, 1998, 29, p. 661-672.

[70] B. Smoljan, S. Smokvina Hanza, N. Tomašić, D. Iljkić. Computer simulation of microstructure transformation in heat treatment processes. Journal of Achievements in Materials and Manufacturing Engineering, 2007, 24, p. 275-282.

[71] H. Yada. Prediction of microstructural changes and mechanical properties in hot strip rolling. Proceedings of the Metallurgical Society of the Canadian Institute of Mining and Metallurgy, 1988, 3, p. 105-119.

[72] N. Yurioka, T. Kasuya, M. Okumura. Methods for Predicting Maximum Hardness of Heat-Affected Zone and Selecting Necessary Preheat Temperature for Steel Welding. Nippon Steel Technical Report, 1995, 65 p. 7-14.

[73] J. Opara, A. Wrożyna. Zastosowanie metody automatów komórkowych do opracowania cyfrowej reprezentacji wybranych cech mikrostruktury w oparciu o obrazy binarne jej składników. Prace Instytutu Metalurgii Żelaza, 2013, 65 (4), p. 2-7.
[74] J. Opara. Fizyczny model przemian fazowych w mezoskali do symulacji procesu wytwarzania blach cienkich ze stali wielofazowych (doctoral dissertation). Gliwice: Instytut Metalurgii Żelaza, 2019. [unpublished].

[75] J. Opara, R. Kuziak. Study of phase transformations in complex phase steel using a mesoscale cellular automaton model. Part II: Experiments and Validation. Journal of Metallic Materials, 2020, 73 (3), p. 32-44.

[76] J.O. Andersson, T. Helander, L. Höglund, P.F. Shi, B. Sundman. Thermo-Calc and DICTRA, Computational tools for materials science. Calphad, 2002, 26, p. 273-312.

[77] Materials Algorithms Project. [Online] Available at: https://www. phase-trans.msm.cam.ac.uk/map/ [Accessed on: 28 August 2020].

[78] H. Springer, M. Belde, D. Raabe. Bulk combinatorial design of ductile martensitic stainless steels through confined martensite-to-austenite reversion. Materials Science \& Engineering A, 2013, 582, p. 235-244.

[79] B.B. He, M.X. Huang. Revealing heterogeneous C partitioning in a medium Mn steel by nanoindentation. Materials Science and Technology, 2017, 33, p. 1-7.

[80] M. Pietrzyk, J. Kusiak, R. Kuziak, L. Madej, D. Szeliga, R. Gołąb. Conventional and Multiscale Modeling of Microstructure Evolution During Laminar Cooling of DP Steel Strips. Metallurgical and Materials Transactions A, 2014, 45, p. 5835-5851. 